\title{
A cell-free organelle-based in vitro system for studying the peroxisomal protein import machinery
}

Tony A. Rodrigues ${ }^{1,2,3^{*}}$, Tânia Francisco ${ }^{1,2^{*}}$, Ana F. Dias ${ }^{1,2,3}$, Ana G. Pedrosa ${ }^{1,2,3}$, Cláudia P. Grou ${ }^{1,2}$, Jorge E. Azevedo ${ }^{1,2,3, \#}$

${ }^{1}$ Instituto de Investigação e Inovação em Saúde (i3S), Universidade do Porto, Rua Alfredo Allen, 208, 4200-135 Porto, Portugal

${ }^{2}$ Instituto de Biologia Molecular e Celular (IBMC), Universidade do Porto, Rua Alfredo Allen, 208, 4200-135 Porto, Portugal

${ }^{3}$ Instituto de Ciências Biomédicas de Abel Salazar (ICBAS), Universidade do Porto, Rua de Jorge Viterbo Ferreira, 228, 4050-313 Porto, Portugal

* These authors contributed equally to this work.

${ }^{\#}$ Corresponding author: jazevedo@ibmc.up.pt

Running head: A peroxisomal in vitro import system

Keywords: Peroxisomes, In vitro import, PEX5, PEX7, Peroxisomal import machinery, Protein translocation, Post-nuclear supernatant, Cell-free import assay

Tony A. Rodrigues; e-mail: tonyr@ibmc.up.pt

Tânia Francisco; e-mail: taniaf@ibmc.up.pt

Ana F. Dias; e-mail: ana.dias@ibmc.up.pt

Ana G. Pedrosa; e-mail: ana.pedrosa@ibmc.up.pt

Cláudia P. Grou; e-mail: cpgrou@ibmc.up.pt

Jorge E. Azevedo; e-mail: jazevedo@ibmc.up.pt, telephone: +351 220408800

This is the peer reviewed version of the following article: Rodrigues, T.A., Francisco, T., Dias, A.F., Pedrosa, A.G., Grou, C.P., Azevedo, J.E. (2016), A cell-free organelle based in vitro system for studying the peroxisomal protein import machinery. Nature Protocols, 11: 2454-2469, which has been published in final form athttps://doi.org/10.1038/nprot.2016.147. This article may be used for non-commercial 
purposes in accordance with Springer Nature Terms and Conditions for Use of SelfArchived Versions.

\begin{abstract}
A cell-free in vitro system to dissect the mechanism of the peroxisomal matrix protein import pathway is described. The system relies on a post-nuclear supernatant, as a source of peroxisomes and cytosolic components, which is generally fortified with specific recombinant proteins to increase yields. A typical in vitro assay comprises the following steps: 1) incubation of the post-nuclear supernatant with an in vitro synthesised ${ }^{35} \mathrm{~S}$-labeled reporter protein; 2) treatment of the organelle suspension with a protease; and 3) SDSPAGE/autoradiography analysis. Both organelle-resident proteins and the corresponding shuttling receptors (PEX5L/S or PEX5L.PEX7) can be used as reporter proteins. Thus, different but complementary perspectives on the mechanism of this pathway can be obtained. The system recapitulates all the steps of the pathway, including monoubiquitination of PEX5L/S at the peroxisome membrane, and its ATP-dependent export back into the cytosol by PEX1/PEX6. An in vitro import(/export) experiment is completed in 24 hours.
\end{abstract}

\title{
INTRODUCTION
}

In their basic configuration, cell-free organelle-based in vitro protein import assays comprise three steps: 1) incubation of an organelle suspension with an in vitro synthesised

${ }^{35}$ S-labeled reporter protein harbouring a specific targeting sequence; 2) treatment of the organelle suspension with a vast amount of an aggressive protease to degrade the nonimported reporter protein; and 3) analysis of organelle proteins by SDSPAGE/autoradiography. The experimental simplicity of these assays together with the fact that they employ a completely open experimental system (meaning that components can be added or removed in a expedite manner) are the reasons why they have been in use for so many decades now, yielding a wealth of information on how mitochondria, chloroplasts, endoplasmic reticulum and peroxisomes import their proteins ${ }^{1-4}$.

The application of this technique to the study of the peroxisomal matrix protein import machinery (PIM) has been particularly informative due to the variety of reporter proteins that can be used in these assays. Indeed, besides organelle-resident proteins containing a peroxisomal targeting signal (PTS) type 1 or a PTS type 2 (see Fig. 1a for details on these PTSs), also the corresponding shuttling receptors, PEX5L/S and the protein complex PEX5L.PEX7, can be used as reporter proteins (note that there are two main isoforms of PEX5, PEX5L and PEX5S; for simplicity we omit the L/S whenever a statement applies to 
both; see also Fig. 1a). Thus, different but complementary perspectives on the PIM, each centered on a different component, can be obtained.

Here we present a detailed protocol to perform these assays as well as several strategies to block the peroxisomal matrix protein import pathway at virtually any step. The protocol provided uses a post-nuclear supernatant (PNS) from mouse or rat liver as a source of peroxisomes and cytosolic components, but other sources (e.g., cultured cells) can also be used. Besides an in vitro synthesised ${ }^{35} \mathrm{~S}$-labeled reporter protein, some common biochemical reagents and protein analysis equipment, only a few easy-to-obtain recombinant proteins are necessary to perform these assays.

\section{Development of the protocol}

Despite their simplicity and the large amounts of mechanistic data they can potentially generate, in vitro protein import systems were not very popular in the peroxisomal protein sorting field for many years. A major problem was the low import yields obtained with many of the reporter proteins tested in the early attempts ${ }^{5-9}$. This, together with a lack of bona fide negative controls, made the interpretation of those experiments a difficult task.

Two main reasons explain why peroxisomes yielded poor results when used in in vitro protein import assays with ${ }^{35} \mathrm{~S}$-labeled matrix proteins as reporters. The first is related to the fact that the PIM is largely partitioned between the peroxisomal membrane and the cytosol. PIM components found mainly in the cytosol include the low abundance proteins PEX5 and PEX7, as well as components of the ubiquitin cascade (see Fig. 1b and Ref. ${ }^{10-12}$ ). This, together with the fact that neither PEX5 nor PEX7 are present in the rabbit reticulocyte lysate (RRL) ${ }^{13,14}$, the system generally used to synthesise ${ }^{35} \mathrm{~S}$-labeled proteins, means that any attempt to use purified peroxisomes or even crude organelle fractions in in vitro import assays programmed with ${ }^{35} \mathrm{~S}$-labeled peroxisomal matrix proteins was poised to produce poor results.

The second reason stems from the fragility of peroxisomes and to the fact that the PTS1 present in the vast majority of peroxisomal matrix proteins is not cleaved upon import ${ }^{15,16}$. Thus, peroxisome suspensions (e.g., a PNS or a highly purified peroxisome fraction) are always contaminated with soluble PTS1-containing proteins that have leaked from the organelles during tissue homogenization, or simple manipulations such as organelle pelleting and resuspension procedures ${ }^{15,17}$. This creates competition phenomena between the ${ }^{35}$ S-labeled reporter protein (be it a PTS1 protein or a PTS2 protein), and the endogenous PTS1 proteins at two crucial steps: 1) interaction with the endogenous shuttling receptor PEX5, and 2) interaction of the cargo protein-PEX5 complexes with the docking/translocation machinery (DTM) (see Fig. 1b).

Almost paradoxically, the reasons behind the poor performance of peroxisomes in in vitro import assays containing ${ }^{35} \mathrm{~S}$-labeled peroxisomal matrix proteins are also those behind the robustness and specificity of the PNS-based PEX5-centered in vitro assay, the first of the four in vitro systems here described to be developed ${ }^{18}$. Indeed, the low abundance of 
endogenous PEX5 in PNS as well as the presence of soluble import-competent PTS1 proteins in these supernatants implies, on one hand, that the few nanograms of ${ }^{35} \mathrm{~S}$-labeled PEX5 protein that are generally used in in vitro assays will not face much competition from the endogenous receptor and, on the other hand, that the ${ }^{35} \mathrm{~S}$-labeled protein can interact with endogenous PTS1 proteins thus yielding the correct substrate for the DTM ${ }^{19}$. Thus, a relatively large fraction of the ${ }^{35}$ S-labeled PEX5 added to these assays engages in protein transport to the peroxisome. This, together with the easily detectable biochemical alterations that PEX5 undergoes during its transient passage through the peroxisome (i.e., acquisition of a protease-protected status and monoubiquitination; ${ }^{20,21}$ ) makes the PEX5centered in vitro assay one of the most useful and informative tools to study the PIM ${ }^{22-25}$. In contrast to the PEX5-centered in vitro assay, which requires nothing else other than the components provided by a PNS and a few chemicals, all the other assays, namely the PEX7-, the PTS2-, and the PTS1-centered in vitro systems require some modifications to the basic protocol. We note that all these modifications are extremely simple but they do increase in a dramatic way the robustness, and thus the specificity, of these assays.

The strategy to increase the import yields of PTS2 proteins from essentially 0 to $5-10 \%$ of the input reporter protein, consists in fortifying the PNS with a recombinant mutant PEX5L protein (e.g., $\triangle \mathrm{C} 1 \mathrm{PEX} 5 \mathrm{~L})$ which still harbours all the domains necessary to interact with the DTM and with the PEX7/PTS2 heterodimer but that is no longer competent in transporting PTS1 proteins to the organelle ${ }^{26}$. In this way, the concentration of PEX5L species competent in the PTS2-mediated protein import pathway is increased (thus compensating the unavoidable dilution of the low abundance endogenous PEX5L protein in the assays) without raising also the concentration of protein complexes comprising PEX5 and endogenous PTS1 proteins, which would compete with the PTS2 reporter protein at the DTM level.

A similar fortification strategy is used in the PEX7-centered in vitro assays. Here, supplementation of the PNS with recombinant $\triangle \mathrm{C} 1 \mathrm{PEX} 5 \mathrm{~L}$ already increases markedly the fraction of ${ }^{35} \mathrm{~S}$-labeled PEX7 that targets the peroxisome, but even better results are obtained when both $\triangle \mathrm{C} 1 \mathrm{PEX} 5 \mathrm{~L}$ and a recombinant PTS2 protein, the precursor of phytanoyl-CoA hydroxylase (prePHYH), are added to the PNS ${ }^{3}$. It should also be noted that the $\triangle$ C1PEX5L.PEX7.prePHYH trimeric complex is extremely stable (half-life of 3 hours). Thus, for some specific purposes it may be advantageous to pre-assemble the trimeric complex in vitro before starting the import/export assay ${ }^{13}$.

Although endogenous PEX5 is surely a limiting factor also in the PTS1-centered in vitro assays, fortifying the PNS with recombinant PEX5 has either no effect or just increases the import yields by a 2-fold factor, depending on the reporter PTS1 protein. The presence of large amounts of endogenous soluble PTS1 proteins in PNS explains this phenomenon - as the concentration of PEX5 in the assay is increased so is the concentration of complexes comprising endogenous PTS1 proteins and PEX5, thus titrating the available DTMs. However, we have recently found that for some reporter PTS1 proteins this problem can be 
circumvented. Indeed, pre-incubation of ${ }^{35}$ S-labeled 2,4-dienoyl-CoA reductase or sterol carrier protein $\mathrm{x}(\mathrm{SCPx})$ with a few nanograms of recombinant PEX5 before starting the import assay dramatically improves their in vitro import yields ${ }^{27}$. In the case of SCPx this effect is particularly strong as import of this protein becomes almost completely dependent on the recombinant PEX5 with which it is pre-incubated. Although we are still lacking detailed data on the PEX5-SCPx interaction, this suggests that this protein complex is particularly stable, as is in fact supported by previous data on the interaction between the Cterminal half of PEX5 and SCP2, a protein identical to the C-terminal fourth of SCPx ${ }^{28}$. Thus, by starting the import assays with a pre-assembled PEX5-SCPx complex, competition between the ${ }^{35}$ S-labeled protein and endogenous PTS1 proteins for PEX5 binding is avoided. Furthermore, because the amount of recombinant PEX5 used in the preincubation step that is carried over to the in vitro import assay is small, the DTM titration problem referred to above is also avoided.

\section{Applications of the method}

The organelle-based in vitro assays described here reproduce all the steps of the peroxisomal matrix protein import pathway. These include: 1) transport of newly synthesised proteins into the peroxisome matrix ${ }^{13,14,26,27}$,2) monoubiquitination of PEX5 at the peroxisomal DTM ${ }^{21,29}$, 3) extraction of monoubiquitinated PEX5 from the DTM into the cytosol by PEX1/PEX6 ${ }^{17,22,25}$, and 4) deubiquitination of PEX5 in the cytosol ${ }^{23,30,31}$. Thus, within a single biological pathway, which can be fully recapitulated in vitro, several different subjects can be addressed, namely protein translocation across biological membranes, RING E3s and protein ubiquitination/deubiquitination, and mechanoenzymes of the AAA family. Given the increasing number of tools and strategies that can be used to block this pathway at virtually any step (see Table 1) it is clear that this experimental system will continue to provide valuable insights into the molecular mechanisms of all this machinery, similarly to what is true with all in vitro systems that have been used to study protein sorting to other organelles ${ }^{1,2,4}$.

The protocol presented here uses post-nuclear supernatants from rat/mouse liver as a source of peroxisomes and cytosolic components (see Box 1). There are two reasons behind this option: 1) peroxisomes are quite abundant in this organ ${ }^{32}$, and 2) a PNS prepared from the liver of a single animal is sufficient to keep several researchers performing daily assays for several months. However, if necessary, PNS prepared from cultured cells can also be used, as described before for human skin fibroblasts from control individuals and Zellweger patients, $\mathrm{CHO}$ and HeLa cells ${ }^{22,33,34}$. Thus, the protocol and experimental strategies presented here can potentially be applied to a variety of other cells (e.g., mouse embryonic fibroblasts) with minor or no adaptations.

Finally, it may be important to note that although we find it particularly convenient to use

${ }^{35} \mathrm{~S}$-labeled reporter proteins in these assays (authentic/untagged reporter proteins can be used; the results are obtained by a simple autoradiography which is semi-quantitative in 
nature; and mammalian reporter proteins synthesised in a rabbit reticulocyte lysate tend to be fully soluble/active) a Western-blot/immunodetection procedure can also be employed to monitor these assays, as previously shown for endogenous rat liver PEX5 ${ }^{17,18}$ and, more recently, for a recombinant tagged version of Arabidopsis thaliana PEX5 ${ }^{24}$. The use of epitope-tagged reporter proteins in these assays is particularly promising because it may also facilitate future attempts to scale-up these assays for more quantitatively demanding purposes, such as structural studies of the DTM.

\section{Comparison with other methods}

Besides organelle-based in vitro assays, only one other type of in vitro assays is currently available to study the PIM. These are all cell-based assays which use semi-permeabilized cultured cells as a source of peroxisomes ${ }^{35-37}$. In brief, cells are semi-permeabilized either mechanically or by treatment with substances that partially solubilize the plasma membrane (e.g., Streptolysin O), incubated with a reporter protein and analysed by (immuno)fluorescence microscopy. In one case, an ELISA-based detection method was coupled to the import assay to better assess the import efficiency of the reporter protein ${ }^{37}$. There are advantages and disadvantages associated with those cell-based assays. The latter include the requirement of a continuous supply of live cells, and the need to use reporter proteins that have to be chemically different from any other protein already present in the semi-permeabilized cells; otherwise it will be difficult to distinguish a reporter protein from its endogenous pool. A major advantage of those assays resides in the fact that the methods used to prepare semi-permeabilized cells are very gentle and comprise a washing step of the cells just before the import assays. Thus, there are no soluble endogenous PTS1 proteins competing with PTS1 or PTS2 reporter proteins in those assays. This is probably the reason why cell-based in vitro import assays, in contrast to the organelle-based assays described here, can be used to study the import pathway of proteins harboring a weak PTS1 (e.g., catalase $\left.^{36}\right)$.

\section{Experimental design}

Organelle-based in vitro assays are very simple to perform and very fast. Preparation of some reagents can consume a few days but since all these can be stored frozen for many months (e.g., the PNS; recombinant proteins) or even years (e.g., plasmids encoding the reporter proteins for in vitro transcription/translation), this part of the work is seldom performed. With the exception of the reduced glutathione and N-ethylmaleimide (NEM) solutions, which are prepared freshly, all reagents are kept at $4{ }^{\circ} \mathrm{C}$ or stored in small aliquots at either $-20^{\circ} \mathrm{C}$ or $-70^{\circ} \mathrm{C}$ and thawed just before starting the in vitro assay.

When performing this type of assays, it is important to know that when a protein, whatever it is, is incubated with an organelle suspension, a fraction of it will always be recovered together with the organelles upon centrifugation (e.g., see Ref. ${ }^{38}$ ). The fraction of that 
protein that sediments with the organelles may simply reflect the amount of supernatant that is always entrapped in the organelle pellet, or may in fact be larger if the protein has some tendency to aggregate or to interact non-specifically with organelle membranes. If, in addition to this phenomenon, one also considers that some proteins may be intrinsically protease-resistant, then it is easy to understand why improperly controlled experiments can provide deceiving conclusions.

The protocol presented here provides a number of independent strategies that efficiently block protein import/export into/from peroxisomes (i.e., negative controls) and thus any unspecific phenomena, as the ones described above, will be easily identified. For instance, addition of recombinant NDPEX14 (see Table 1) to an import assay completely blocks the PEX5-, PEX7-, PTS1-, and PTS2-centered in vitro assays, whereas addition of a vast excess of recombinant prePHYH to an in vitro assay programmed with a ${ }^{35}$ S-labeled PTS2 protein will block (compete with) import of the reporter protein without blocking insertion of PEX7 into the peroxisomal DTM. Likewise, addition of a recombinant protein comprising the PTS1-binding domain of PEX5 (referred to as TPRs; see Table 1) to a $\mathrm{PEX} 5$-centered in vitro assay, or its presence in the pre-incubation mixture containing ${ }^{35} \mathrm{~S}$ labeled SCPX and recombinant PEX5, will block the PTS1-dependent insertion of ${ }^{35} \mathrm{~S}-$ labeled PEX5 into the DTM and peroxisomal import of ${ }^{35} \mathrm{~S}$-labeled SCPx, respectively.

Another frequently used strategy to ensure that an in vitro assay is working properly consists in assessing the amounts of reporter protein that acquire an organelle-associated, protease-protected status in a time- and temperature-dependent manner. Naturally, after protease treatment no reporter protein should be detected in organelles in the 0-min time point and the same result should be obtained when the in vitro assay is performed at $0-4{ }^{\circ} \mathrm{C}$, because insertion of receptor-cargo protein complexes into the DTM does not occur at this temperature ${ }^{26,27}$. Although these experiments should not be taken as true negative controls (artifacts may also be time- and/or temperature-dependent), an unexpected result (e.g., "import" in a $0-4{ }^{\circ} \mathrm{C}$ sample) indicates the existence of problems with either the reporter protein or the proteolysis conditions.

The experimental conditions used here in the protease-treatment step are rather harsh: 500$600 \mu \mathrm{g}$ of total PNS protein containing 1-2 $\mu \mathrm{L}$ of a rabbit reticulocyte lysate in a $100 \mu \mathrm{L}$ volume are treated with $40 \mu \mathrm{g}$ of an aggressive protease (e.g., proteinase $\mathrm{K}$ or pronase) for 30-45 min on ice. For the reporter proteins used here, these conditions are far in excess of those required to completely degrade the soluble ${ }^{35} \mathrm{~S}$-labeled proteins under identical conditions. However, this is not necessarily true for other proteins, many of which are actually peroxisomal matrix proteins. Thus, when using a reporter protein for the first time its intrinsic susceptibility to aggressive proteases has to be determined. This is easily performed by incubating $0.5-1 \mu \mathrm{L}$ aliquots of the RRL containing the ${ }^{35} \mathrm{~S}$-labeled protein with different concentrations of a protease (e.g., proteinase $\mathrm{K}$, pronase or trypsin) in $100 \mu \mathrm{L}$ of import buffer, and following steps 6-B-ii, 6-A-iv and 7-11 of the main protocol. Samples are then analysed by SDS-PAGE/Western-blot/autoradiography, as described (see also Box 2). 
Once the robustness and specificity of the in vitro assays is established, many different tools/strategies can be used to block the PIM at different steps. Some of these are as simple as decreasing the temperature of the assays, or adding non-hydrolysable ATP analogs, whereas others require mutant versions of the recombinant or ${ }^{35} \mathrm{~S}$-labeled proteins mentioned here. A summary of all the tools/strategies currently used is presented in Table 1 .

\section{Limitations}

The PEX5-, PEX7-, and PTS2-centered in vitro assays are all very robust. However, the PTS1-centered in vitro system still presents some limitations. Indeed, not all PTS1containing cargo proteins can be used in these assays. For instance, proteins such as catalase, alanine glyoxylate aminotransferase and glutathione S-transferase $\kappa 1$ show no, or almost no, import when used in these assays. A possible reason for this may be the weak PTS1 they harbour ${ }^{39}$, which probably translates into short half-lives of their complexes with PEX5. Thus, a pre-incubation step with recombinant PEX5 before in vitro import, the strategy used here for SCPx, does not really improve their import yields because the complexes probably dissociate in a few seconds after starting the import assay.

The in vitro system described here can be used in biochemical complementation assays to identify and/or characterize components of the peroxisomal protein import machinery other than just PEX5 and PEX7 (e.g., the ubiquitin conjugation enzymes E2D1/2/3 ${ }^{33}$, the deubiquitinase USP9X ${ }^{30}$, and the adaptor protein AWP1 ${ }^{40}$ ). However, due to the fact that organelles from wild type rat/mouse are used in this protocol, only soluble components can be studied in this manner because only these can be removed from or added to the organelle suspension. Clearly, for the membrane-embedded components of the peroxisomal protein import machinery other approaches will have to be used.

\section{MATERIALS}

\section{REAGENTS}

- Male rat or mouse with 6-10 weeks of age fasted overnight (e.g., specific pathogen free Wistar Han rat (strain code: 273) or C57BL/6 mouse (strain code: 027) from Charles River). The animals used here were handled in accordance with the protocols approved by the IBMC Animal Ethics Committee (CEA - Comissão de Ética Animal). Experimental protocols were approved by the Portuguese General Veterinarian Board (DGAV - Direcção Geral de Alimentação e Veterinária). ! CAUTION Experiments using rodents must conform to national and institutional regulations.

- Plasmids encoding PEX5L (pGEM4-PEX5 18), PEX7 (pGEM4-PEX7 ${ }^{3}$ ), SCPX (pGEM4-SCPx ${ }^{27}$ ) and pre-thiolase (pGEM4-pre-thiolase ${ }^{26}$ ) for in vitro 
transcription/translation (all available on request). Plasmid DNA is prepared using a standard miniprep kit (e.g., Qiagen, cat. no. 27104).

- Plasmids encoding the following N-terminally histidine-tagged proteins for expression in Escherichia coli: PEX5L, $\triangle$ C1PEX5L, NDPEX14 (all available on request), and prePHYH $^{41}$ (see Box 3).

- 3-(N-Morpholino)propanesulfonic acid (MOPS) (Sigma-Aldrich, cat. no. M1254)

- Adenosine 5'-( $\beta, \gamma$-imido)triphosphate lithium salt hydrate (AMP-PNP) (Sigma-Aldrich, cat. no. A2647)

- Acetone (Merck, cat. no. 100014)

- ATP disodium salt hydrate (Sigma-Aldrich, cat. no. A2383)

- Bromophenol blue (Sigma-Aldrich, cat. no. B5525)

- Di-sodium hydrogen phosphate $\left(\mathrm{Na}_{2} \mathrm{HPO}_{4}\right)$ (Merck, cat. no. 106586)

- Dithiothreitol (DTT) (Calbiochem ${ }^{\circledR}$, cat. no. 233155)

- EasyTag ${ }^{\mathrm{TM}} \mathrm{L}-\left[{ }^{35} \mathrm{~S}\right]-\mathrm{Methionine,} 1 \mathrm{mCi}(37 \mathrm{MBq})$, Stabilized Aqueous Solution (Perkin Elmer, cat. no. NEG709A001MC) $\left({ }^{35} \mathrm{~S}-\mathrm{Met}\right)$ ! CAUTION Radioactive compound. Safety precautions are required. Check that your institution holds the appropriate license for radioisotope usage.

- Ethanol (PanReac AppliChem, cat. no. 121086) ! CAUTION Highly flammable.

- Ethylenedinitrilotetraacetic acid disodium salt dihydrate (EDTA) (Merck, cat. no.108421) ! CAUTION Toxic, avoid inhalation.

- $\mathrm{HCl}$ (Merck, cat. no. 100317) ! CAUTION Very corrosive. Avoid exposure.

- $\quad$ HIS-Select ${ }^{\circledR}$ Nickel Affinity Gel (Sigma-Aldrich, cat. no. P6611)

- Imidazole (Sigma-Aldrich, cat. no. I0125)

- Isopropyl $\beta$-D-1-thiogalactopyranoside (IPTG) (Calbiochem ${ }^{\circledR}$, cat. no. 420322)

- $\mathrm{KCl}$ (Merck, cat. no. 104936)

- $\mathrm{KOH}$ (Merck, cat. no.105033) ! CAUTION Corrosive and toxic, avoid contact and spillage.

- L-Glutathione reduced (GSH) (Sigma-Aldrich, cat. no. G4251)

- Liquid nitrogen ! CAUTION Extremely cold. Handle with care.

- L-Methionine (Met) (Sigma-Aldrich, cat. no. M9625)

- Luria Broth (LB) and LB agar plates with the appropriate antibiotics (see Box 3)

- $\mathrm{MgCl}_{2}$ (Merck, cat. no. 105833)

- $\quad \mathrm{N}$-(trans-epoxysuccinyl)-L-leucine 4-guanidinobutylamide (E-64) (Sigma-Aldrich, cat. no. E3132)

- $\mathrm{NaCl}$ (Merck, cat. no. 106404)

- $\mathrm{NaOH}$ (Merck, cat. no. 106498) ! CAUTION Very corrosive. Avoid exposure.

- N-ethylmaleimide (NEM) (Sigma-Aldrich, cat. no. E3876) ! CAUTION Very toxic. Avoid exposure.

- Nitrocellulose membrane $0.45 \mu \mathrm{m}$ (e.g., Amersham, cat. no. 10600002) 
- Phenylmethylsulfonyl fluoride (PMSF) (Sigma-Aldrich, cat. no. P7626) ! CAUTION Corrosive and toxic. Avoid exposure.

- Ponceau S (Sigma-Aldrich, cat. no. P3504)! CAUTION Toxic. Avoid exposure.

- Protease from Streptomyces griseus type XIV (Pronase) (Sigma-Aldrich, cat. no. P5147) ! CAUTION Toxic. Avoid exposure.

- Protease inhibitor cocktail (Sigma-Aldrich, cat. no. P8340)

- Proteinase K from Tritirachium album (PK) (Sigma-Aldrich, cat. no. P2308) ! CAUTION Toxic. Avoid exposure.

- Sodium dihydrogen phosphate monohydrate $\left(\mathrm{NaH}_{2} \mathrm{PO}_{4} * \mathrm{H}_{2} \mathrm{O}\right)$ (Merck, cat. no. 106346)

- Sucrose (Sigma-Aldrich, cat. no. S0389)

- $\quad$ TNT $^{\circledR}$ T7 Quick Coupled Transcription/Translation System (Promega, cat. no. L1170)

- Trichloroacetic acid (TCA) (PanReac AppliChem, cat. no. 131067) ! CAUTION Very corrosive. Avoid exposure.

- Tris(hydroxymethyl)aminomethane (Tris) (Merck, cat. no. 108382)

- Triton $^{\mathrm{TM}}$ X-100 (TX-100) (Sigma-Aldrich, cat. no. T9284)

- Ubiquitin aldehyde (Ubal) (e.g., Enzolifesciences, cat. no. BML-UW8450-0050)

- Ubiquitin from bovine erythrocytes (Ub) (Sigma-Aldrich, cat. no. U6253)

- Vivaspin ${ }^{\circledR} 2$ Sample Concentrators (GE Healthcare Life Sciences, cat. no. 28932247)

- X-ray film (e.g., Kodak BioMax ${ }^{\circledR}$ MR, VWR, cat. no. 730-3241)

\section{EQUIPMENT}

- Hair dryer

- Heating plate (e.g., VMS-A, VWR, cat. no. 442-0185)

- High-speed centrifuge (e.g., Sorvall RC5B Plus with SS-34 and GS3 rotors and the corresponding tubes)

- Low-speed microcentrifuge (e.g., VWR MiniStar silverline, cat. no. 521-2844)

- Medium-speed centrifuge with adaptors for $15 \mathrm{~mL}$ falcon tubes (e.g., Hettich Universal 320R, Sigma-Aldrich, cat. no. Z722871)

- Orbital shaker incubator or shaking water bath for liquid bacterial cultures

- Overhead stirrer (e.g., Sigma-Aldrich, cat. no. Z336645) equipped with a PotterElvehjem Teflon pestle and glass tube (tight fitting) (Sigma-Aldrich, cat. no. P7984)

- Petri dish

- $\mathrm{pH}$ meter (e.g., WTW Inolab pH 720, GeminiBV, cat. no. 3321 HWK)

- Refrigerated microcentrifuge (e.g., Eppendorf ${ }^{\circledR} 5418 \mathrm{R}$, cat. no. 5401000013)

- Scissors

- Sonopuls HD 2200 Sonicator (Bandelin electronic, cat. no. HD2200) equipped with a MS 73 tip (Bandelin electronic, cat. no. 492)

- Spectrophotometer (e.g., Thermo Scientific Genesys 10S, cat. no. 840-208100) 
- Standard equipment and solutions required to perform SDS-PAGE/Westernblot/autoradiography

- Thermomixer (e.g., Eppendorf ${ }^{\circledR}$ Comfort, Sigma-Aldrich, cat. no. T3317)

\section{REAGENT SETUP}

$\triangle$ CRITICAL STEP Doubly distilled and deionized water $\left(\mathrm{ddH}_{2} \mathrm{O}\right)$ should be used to prepare all aqueous solutions.

0.1 M ATP pH 7.0 Dissolve $275.57 \mathrm{mg}$ of ATP disodium salt in $4 \mathrm{~mL}$ of water and add $100 \mu \mathrm{L}$ of $1 \mathrm{M}$ MOPS-KOH $\mathrm{pH}$ 7.2. After adjusting $\mathrm{pH}$ to $\sim 7.0$ with $5 \mathrm{M} \mathrm{NaOH}$, make up to $5 \mathrm{~mL}$ with water. Store $500-\mu \mathrm{L}$ aliquots at $-70{ }^{\circ} \mathrm{C}$. Stable for at least one year.

1 M DTT Dissolve $1.5 \mathrm{~g}$ of DTT in $10 \mathrm{~mL}$ (final volume) of water. Store $500-\mu \mathrm{L}$ aliquots at $-20{ }^{\circ} \mathrm{C}$. Stable for several months.

0.4 mg/mL E-64 Dissolve $4 \mathrm{mg}$ of E-64 in $9.9 \mathrm{~mL}$ of water and add $100 \mu \mathrm{L}$ of $1 \mathrm{M}$ MOPS$\mathrm{KOH} \mathrm{pH}$ 7.2. Store $500-\mu \mathrm{L}$ aliquots at $-20^{\circ} \mathrm{C}$. Stable for several months.

0.5 M EDTA-NaOH pH 8.0 Add $18.6 \mathrm{~g}$ of EDTA to $70 \mathrm{~mL}$ of water. Adjust $\mathrm{pH}$ to 8.0 with $5 \mathrm{M} \mathrm{NaOH}$ and make up to $100 \mathrm{~mL}$ with water. Store at room temperature $\left(\sim 23{ }^{\circ} \mathrm{C}\right)$. Stable for several months.

$20 \%$ (v/v) Ethanol Dilute $20 \mathrm{~mL}$ of ethanol in $100 \mathrm{~mL}$ (final volume) of water. Store at room temperature. Stable for years.

0.1 M GSH Dissolve $30.73 \mathrm{mg}$ of GSH in $500 \mu \mathrm{L}$ of water. Add $20 \mu \mathrm{L}$ of 1 M MOPS$\mathrm{KOH} \mathrm{pH} 7.2$ and adjust $\mathrm{pH}$ to $\sim 7.0$ with $5 \mathrm{M} \mathrm{NaOH}$. Make up to $1 \mathrm{~mL}$ with water. $\triangle$ CRITICAL STEP This solution should be prepared freshly and kept on ice.

1 M Imidazole Dissolve $6.8 \mathrm{~g}$ of imidazole in $100 \mathrm{~mL}$ (final volume) of water. Store at 4 ${ }^{\circ} \mathrm{C}$ in the dark. Stable for at least two years.

1 M IPTG Dissolve $477 \mathrm{mg}$ of IPTG in $2 \mathrm{~mL}$ (final volume) of water. Store 500- $\mu \mathrm{L}$ aliquots at $-20^{\circ} \mathrm{C}$. Stable for at least one year.

$3 \mathrm{M}$ KCl Dissolve $11.2 \mathrm{~g}$ of $\mathrm{KCl}$ in $50 \mathrm{~mL}$ (final volume) of water. Store at room temperature. Stable for years. 
5 M KOH Dissolve $28.1 \mathrm{~g}$ of $\mathrm{KOH}$ in $100 \mathrm{~mL}$ (final volume) of water. Store at room temperature. Stable for at least one year. ! CAUTION Corrosive and toxic, avoid contact and spillage.

$3 \mathrm{~g} / \mathrm{L}$ L-Methionine Dissolve $30 \mathrm{mg}$ of methionine in $10 \mathrm{~mL}$ (final volume) of water. Store $500-\mu \mathrm{L}$ aliquots at $-20^{\circ} \mathrm{C}$. Stable for years.

$2 \mathbf{M ~ M g C l}_{2}$ Dissolve $20.3 \mathrm{~g}$ of $\mathrm{MgCl}_{2}$ in $50 \mathrm{~mL}$ (final volume) of water. Store at room temperature. Stable for at least one year.

1 M MOPS-KOH pH 7.2 Dissolve $20.9 \mathrm{~g}$ of MOPS in $60 \mathrm{~mL}$ of water, adjust $\mathrm{pH}$ to 7.2 $\left(20{ }^{\circ} \mathrm{C}\right.$ ) using a $5 \mathrm{M} \mathrm{KOH}$ solution and make up to $100 \mathrm{~mL}$ with water. Store at $4{ }^{\circ} \mathrm{C}$. Stable for at least six months.

5 M NaCl Dissolve $29.2 \mathrm{~g}$ of $\mathrm{NaCl}$ in $100 \mathrm{~mL}$ (final volume) of water. Store at room temperature. Stable for years.

$5 \mathrm{M} \mathrm{NaOH}$ Dissolve $20 \mathrm{~g}$ of $\mathrm{NaOH}$ in $100 \mathrm{~mL}$ (final volume) of water. Store at room temperature. Stable for at least one year. ! CAUTION Very corrosive. Avoid exposure.

0.1 M NEM Dissolve $6.25 \mathrm{mg}$ of NEM in $500 \mu \mathrm{L}$ of water. $\triangle$ CRITICAL STEP Prepare fresh and keep on ice. ! CAUTION Extremely hazardous! Handle with care.

$50 \mathrm{mg} / \mathrm{mL}$ PMSF Dissolve $50 \mathrm{mg}$ of PMSF in $1 \mathrm{~mL}$ (final volume) of ethanol. Store at -20 ${ }^{\circ} \mathrm{C}$. Stable for at least one year. ! CAUTION Corrosive and toxic. Avoid exposure.

Ponceau S solution Dissolve $0.2 \mathrm{~g}$ of Ponceau $\mathrm{S}$ and $3 \mathrm{~g}$ of TCA in $100 \mathrm{~mL}$ (final volume) of water. Store at room temperature. ! CAUTION This solution contains TCA. Handle with care. Stable for at least one year.

$20 \mathrm{mg} / \mathrm{mL}$ Protease (PK or pronase) Dissolve $10 \mathrm{mg}$ of the protease in $490 \mu \mathrm{L}$ of water plus $10 \mu \mathrm{L}$ of $1 \mathrm{M}$ MOPS-KOH pH 7.2. Centrifuge solution at $11,300 \mathrm{~g}$ for $15 \mathrm{~min}$ at $4{ }^{\circ} \mathrm{C}$ and store single use $25-\mu \mathrm{L}$ aliquots of the supernatant at $-70^{\circ} \mathrm{C}$. Stable for at least one year.

Radioactive ink Dilute $2 \mu \mathrm{L}$ of ${ }^{35} \mathrm{~S}-\mathrm{Met}$ in $1 \mathrm{~mL}$ of $20 \%(\mathrm{v} / \mathrm{v})$ ethanol. Spike with some grains of bromophenol blue. Store at room temperature. Stable for several months. ! CAUTION Radioactive compound. Safety precautions are required.

0.5 M Sodium phosphate buffer pH 8.0 Prepare $50 \mathrm{~mL}$ of $0.5 \mathrm{M} \mathrm{Na}_{2} \mathrm{HPO}_{4}$ by dissolving $3.5 \mathrm{~g}$ in $50 \mathrm{~mL}$ (final volume) of water. Prepare $50 \mathrm{~mL}$ of $0.5 \mathrm{M} \mathrm{NaH}_{2} \mathrm{HPO}_{4}$ by dissolving 
$3.4 \mathrm{~g}$ in $50 \mathrm{~mL}$ (final volume) of water. Adjust the $\mathrm{pH}$ of the $0.5 \mathrm{M} \mathrm{Na}_{2} \mathrm{HPO}_{4}$ solution to pH 8.0 with $0.5 \mathrm{M} \mathrm{NaH}_{2} \mathrm{PO}_{4}$. Store at $4{ }^{\circ} \mathrm{C}$. Stable for at least one year.

$\mathbf{1 0 0 \%}$ (w/v) TCA Dissolve $100 \mathrm{~g}$ of TCA in $100 \mathrm{~mL}$ (final volume) of water. Store at room temperature. ! CAUTION Very corrosive. Avoid exposure. Stable for at least one year.

1 M Tris pH 8.0 Dissolve $12.1 \mathrm{~g}$ in $70 \mathrm{~mL}$ of water. Adjust $\mathrm{pH}$ to 8.0 with concentrated $\mathrm{HCl}$ and make up to $100 \mathrm{~mL}$. Store at $4{ }^{\circ} \mathrm{C}$. Stable for at least one year.

$\mathbf{2 0 \%}(\mathbf{w} / \mathbf{v})$ TX-100 Dilute $20 \mathrm{~g}$ of TX-100 in $100 \mathrm{~mL}$ (final volume) of water. Store at 4 ${ }^{\circ} \mathrm{C}$. Stable for at least one year.

$1.25 \mathrm{mM}$ Ub Dissolve $5.35 \mathrm{mg}$ of bovine ubiquitin in $500 \mu \mathrm{L}$ of water. Store $100-\mu \mathrm{L}$ aliquots at $-70{ }^{\circ} \mathrm{C}$. Stable for at least one year.

Import buffer 6x Import buffer $6 \mathrm{x}$ is $1.5 \mathrm{M}$ sucrose, $300 \mathrm{mM} \mathrm{KCl,} 120 \mathrm{mM}$ MOPS pH $7.2,18 \mu \mathrm{g} / \mathrm{mL}$ methionine and $18 \mathrm{mM} \mathrm{MgCl}_{2}$. Dissolve $5.1 \mathrm{~g}$ of sucrose in $1.2 \mathrm{~mL}$ of $1 \mathrm{M}$ MOPS-KOH pH 7.2, $1 \mathrm{~mL}$ of $3 \mathrm{M} \mathrm{KCl}, 90 \mu \mathrm{L}$ of $2 \mathrm{M} \mathrm{MgCl}_{2}$, and water to $10 \mathrm{~mL}$ (final volume). Store $250-\mu \mathrm{L}$ aliquots at $-20{ }^{\circ} \mathrm{C}$. Stable for at least one year. Before using, supplement the $250-\mu \mathrm{L}$ aliquot with $1.5 \mu \mathrm{L}$ of $3 \mathrm{~g} / \mathrm{L}$ methionine.

SEM buffer SEM buffer is $0.25 \mathrm{M}$ sucrose, $20 \mathrm{mM}$ MOPS-KOH pH 7.2 and $1 \mathrm{mM}$ EDTA-NaOH pH 8.0. Dissolve $21.4 \mathrm{~g}$ of sucrose in $100 \mathrm{~mL}$ of water. Add $5 \mathrm{~mL}$ of $1 \mathrm{M}$ MOPS-KOH pH 7.2, $0.5 \mathrm{~mL}$ of $0.5 \mathrm{M}$ EDTA-NaOH pH 8.0, and make up to $250 \mathrm{~mL}$ with water. Store at $4{ }^{\circ} \mathrm{C}$, stable for several weeks.

SEMK buffer SEMK buffer is SEM buffer supplemented with $80 \mathrm{mM} \mathrm{KCl}$. Dissolve 21.4 $\mathrm{g}$ of sucrose in $100 \mathrm{~mL}$ of water. Add $5 \mathrm{~mL}$ of $1 \mathrm{M}$ MOPS-KOH pH 7.2, $6.67 \mathrm{~mL}$ of $3 \mathrm{M}$ $\mathrm{KCl}, 0.5 \mathrm{~mL}$ of $0.5 \mathrm{M}$ EDTA-NaOH $\mathrm{pH} 8.0$, and make up to $250 \mathrm{~mL}$ with water. Store at 4 ${ }^{\circ} \mathrm{C}$, stable for several weeks.

Bacteria lysis buffer A Lysis buffer A is $50 \mathrm{mM}$ Tris pH 8.0, $150 \mathrm{mM} \mathrm{NaCl}, 1 \mathrm{mM}$ DTT, $0.1 \%(\mathrm{w} / \mathrm{v}) \mathrm{TX}-100,50 \mu \mathrm{g} / \mathrm{mL}$ PMSF and 1:1000 (v/v) of protease inhibitor cocktail. Mix 5 $\mathrm{mL}$ of $1 \mathrm{M}$ Tris $\mathrm{pH} 8.0,3 \mathrm{~mL}$ of $5 \mathrm{M} \mathrm{NaCl}$ and $500 \mu \mathrm{L}$ of $20 \%$ (w/v) TX-100. Make up to $100 \mathrm{~mL}$ with water and store at $4{ }^{\circ} \mathrm{C}$. Stable for several months. Before using, supplement $30 \mathrm{~mL}$ with $30 \mu \mathrm{L}$ of $1 \mathrm{M}$ DTT, $30 \mu \mathrm{L}$ of $50 \mathrm{mg} / \mathrm{mL}$ PMSF and $30 \mu \mathrm{L}$ of protease inhibitor cocktail.

Bacteria lysis buffer B Lysis buffer B is $20 \mathrm{mM}$ sodium phosphate buffer $\mathrm{pH} 8.0,500 \mathrm{mM}$ $\mathrm{NaCl}, 0.1 \%$ (w/v) TX-100, $10 \mathrm{mM}$ imidazole, $50 \mu \mathrm{g} / \mathrm{mL}$ PMSF and 1:1000 (v/v) of protease inhibitor cocktail. Mix $4 \mathrm{~mL}$ of $0.5 \mathrm{M}$ sodium phosphate buffer $\mathrm{pH} 8.0,10 \mathrm{~mL}$ of 
$5 \mathrm{M} \mathrm{NaCl}, 1 \mathrm{~mL}$ of $1 \mathrm{M}$ imidazole and $500 \mu \mathrm{L}$ of $20 \%(\mathrm{w} / \mathrm{v}) \mathrm{TX}-100$. Make up to $100 \mathrm{~mL}$ with water and store at $4{ }^{\circ} \mathrm{C}$. Stable for several months. Before using, supplement $30 \mathrm{~mL}$ with $30 \mu \mathrm{L}$ of $50 \mathrm{mg} / \mathrm{mL}$ PMSF and $30 \mu \mathrm{L}$ of protease inhibitor cocktail.

Washing buffer A Washing buffer A is $50 \mathrm{mM}$ sodium phosphate buffer $\mathrm{pH} 8.0,150 \mathrm{mM}$ $\mathrm{NaCl}$. Mix $10 \mathrm{~mL}$ of $0.5 \mathrm{M}$ sodium phosphate buffer $\mathrm{pH} 8.0$ with $3 \mathrm{~mL}$ of $5 \mathrm{M} \mathrm{NaCl}$ and make up to $100 \mathrm{~mL}$ with water. Store at $4{ }^{\circ} \mathrm{C}$. Stable for several months.

Washing buffer B Washing buffer B is $50 \mathrm{mM}$ sodium phosphate buffer $\mathrm{pH} 8.0,500 \mathrm{mM}$ $\mathrm{NaCl}$. Mix $10 \mathrm{~mL}$ of $0.5 \mathrm{M}$ sodium phosphate buffer $\mathrm{pH} 8.0$ with $10 \mathrm{~mL}$ of $5 \mathrm{M} \mathrm{NaCl}$ and make up to $100 \mathrm{~mL}$ with water. Store at $4{ }^{\circ} \mathrm{C}$. Stable for several months.

Elution buffer Elution buffer is $50 \mathrm{mM}$ sodium phosphate buffer $\mathrm{pH} 8.0,150 \mathrm{mM} \mathrm{NaCl}$, $250 \mathrm{mM}$ imidazole, $1 \mathrm{mM}$ DTT. Mix $1.5 \mathrm{~mL}$ of $0.5 \mathrm{M}$ sodium phosphate buffer $\mathrm{pH} 8.0$, $450 \mu \mathrm{L}$ of $5 \mathrm{M} \mathrm{NaCl}, 3.75 \mathrm{~mL}$ of $1 \mathrm{M}$ imidazole and $15 \mu \mathrm{L}$ of $1 \mathrm{M}$ DTT, and make up to 15 $\mathrm{mL}$ with water. Prepare fresh and keep on ice.

Protein storage buffer Storage buffer is $50 \mathrm{mM}$ Tris $\mathrm{pH} 8.0,150 \mathrm{mM} \mathrm{NaCl}, 1 \mathrm{mM}$ EDTA$\mathrm{NaOH} \mathrm{pH} 8.0,1 \mathrm{mM}$ DTT. Mix $5 \mathrm{~mL}$ of $1 \mathrm{M}$ Tris $\mathrm{pH} 8.0,3 \mathrm{~mL}$ of $5 \mathrm{M} \mathrm{NaCl}, 200 \mu \mathrm{L}$ of $0.5 \mathrm{M}$ EDTA-NaOH pH 8.0, and make up to $100 \mathrm{~mL}$ with water. Store at $4{ }^{\circ} \mathrm{C}$. Stable for several months. Before using, supplement $20 \mathrm{~mL}$ with $20 \mu \mathrm{L}$ of DTT $1 \mathrm{M}$ and keep on ice.

Rat/mouse liver post-nuclear supernatant in SEM (see Box 1).

${ }^{35}$ S-labeled reporter protein (e.g., PEX5L, PEX7, pre-thiolase, or SCPx) Synthesize using the $\mathrm{TNT}^{\circledR} \mathrm{T} 7$ Quick Coupled Transcription/Translation System as per manufacturer instructions (see Box 2). Aliquots can be stored at $-70^{\circ} \mathrm{C}$ for a few months.

Histidine-tagged recombinant proteins: PEX5L, $\triangle \mathrm{C} 1 \mathrm{PEX} 5 \mathrm{~L}, \mathrm{NDPEX} 14$, and prePHYH (see Box 3).

\section{PROCEDURE}

\section{In vitro import(/export) protocol $\bullet$ TIMIING 3-5 hours}

1. Rapidly thaw, while gently mixing, an aliquot of the rabbit reticulocyte lysate containing the relevant ${ }^{35} \mathrm{~S}$-labeled reporter protein. Immediately put it on ice and dilute it according to Table 2. The volumes provided are for two import(/export) reactions. Scale-up volumes as needed for a different number of reactions. Also, increase all volumes by $10 \%$ because they are not additive. 
$\triangle$ CRITICAL STEP The amount of ${ }^{35}$ S-lysate may be decreased or increased depending on the specific activity of the radiolabeled protein. Pre-dilution of the lysate in import buffer decreases pipetting errors in subsequent steps.

2. Prepare the PNS mix according to Table 3.

$\triangle$ CRITICAL STEP PNS should be quickly thawed in your hands, gently tapping the tube several times. Once thawed, place it on ice and use immediately. Any thawed PNS that is not used is discarded.

3. (Optional) Prime the PNS for import by incubating it $5 \mathrm{~min}$ at $37^{\circ} \mathrm{C}$.

$\triangle$ CRITICAL STEP This is a mandatory step only when using experimental conditions that block export of PEX5 from the DTM (e.g., assays containing AMPPNP, GST-Ub, or apyrase; see Table 1). If the PNS is not primed for import, endogenous PEX5 at the peroxisomal DTM will not be extracted by the ATPdependent export machinery and therefore the number of available DTMs will be small. Whenever this is not the case, skip this step.

4. Assemble the final reactions according to Table 4 .

5. Gently flick the tube to mix the components, spin down for $1 \mathrm{sec}$ in a low-speed microcentrifuge to collect all the content at the bottom of the tube and incubate for 30 $\min$ at $37^{\circ} \mathrm{C}$.

6. In vitro import(/export) assays generally include a protease treatment step to degrade reporter proteins that did not enter peroxisomes. However, this also destroys the soluble pools of shuttling receptors that travelled through the DTM during step 5. Thus, two options are provided here, one in which the protease treatment step is skipped (option A) and the other which includes it (option B). Option A is particularly informative in the PEX5-centered assay due to the fact that PEX5 is monoubiquitinated during its passage through the DTM. It can also be applied to PEX7, but in this case a two-step import/export strategy would have to be followed (see Ref. ${ }^{3}$ ) because PEX7 is not covalently modified at the DTM.

A) Analysis of organelle and cytosolic proteins (no protease treatment):

i) Place the tubes on ice, add $25 \mu \mathrm{L}$ of $0.1 \mathrm{M} \mathrm{NEM} \mathrm{(20} \mathrm{mM} \mathrm{final} \mathrm{concentration)}$ to each sample and incubate for $5 \mathrm{~min}$.

$\triangle$ CRITICAL STEP NEM is a powerful alkylating agent that is commonly used to stop ubiquitination/deubiquitination reactions. It also neutralizes other thiol groups that might disrupt the ubiquitin-PEX5 thioester bond during sample processing/analysis. 
ii) Dilute the reactions gently to $1 \mathrm{~mL}$ with ice-cold SEMK. Centrifuge at $11,300 \mathrm{~g}$ for 15 min at $4{ }^{\circ} \mathrm{C}$.

iii) Transfer $500 \mu \mathrm{L}$ of the supernatants (equivalent to $250 \mu \mathrm{g}$ of PNS) to a new microtube. Discard the remaining supernatant.

$\triangle$ CRITICAL STEP Avoid cross-contamination between pellet and supernatant. If necessary, after removing most of the supernatant, briefly spin down the tube and remove any traces of supernatant using a $100 \mu \mathrm{L}$ pipette.

iv) Precipitate the pellets and the supernatants with $10 \%$ (w/v) TCA (final concentration): add $55 \mu \mathrm{L}$ of $100 \%$ (w/v) TCA to the supernatants, and $550 \mu \mathrm{L}$ of $10 \%(\mathrm{w} / \mathrm{v})$ TCA to the organelle pellets. Proceed to step 7.

! CAUTION TCA is very corrosive. Handle with care.

B) Analysis of organelle-associated protease-protected proteins (protease treatment):

i) Place the tubes on ice, add $2 \mu \mathrm{L}$ of the selected protease at $20 \mathrm{mg} / \mathrm{mL}$ (400 $\mu \mathrm{g} / \mathrm{mL}$ final concentration), mix gently, spin down for $1 \mathrm{sec}$ in a low-speed microcentrifuge and incubate for $40 \mathrm{~min}$ on ice.

$\triangle$ CRITICAL STEP The protease solution should be quickly thawed in hands, put on ice, and promptly used.

$\triangle$ CRITICAL STEP A brief spin down is critical to ensure that the entire sample gets in contact with the protease.

ii) Add $1 \mu \mathrm{L}$ of PMSF $50 \mathrm{mg} / \mathrm{mL}$, mix gently, spin down $1 \mathrm{sec}$ in a low-speed microcentrifuge and incubate for $2 \mathrm{~min}$ on ice to inactivate the protease.

$\triangle$ CRITICAL STEP PMSF in the stock solution precipitates on ice. Before use, keep it at room temperature $\left(\sim 23^{\circ} \mathrm{C}\right)$ and, if necessary, vortex to ensure all PMSF is in solution.

$\triangle$ CRITICAL STEP A brief spin down is critical to ensure that all protease gets in contact with PMSF.

iii) Dilute the reactions gently to $1 \mathrm{~mL}$ with ice-cold SEMK. Centrifuge at $11,300 \mathrm{~g}$ for $15 \mathrm{~min}$ at $4{ }^{\circ} \mathrm{C}$ to isolate the organelles.

iv) Discard the supernatant.

$\triangle$ CRITICAL STEP The supernatant should be thoroughly removed. If necessary, after removing most of it, briefly spin down the tube and remove all traces using a $100 \mu \mathrm{L}$ pipette.

v) Add $1 \mathrm{~mL}$ of $10 \%(\mathrm{w} / \mathrm{v})$ TCA to the organelle pellets.

! CAUTION TCA is very corrosive. Handle with care. 
$\triangle$ CRITICAL STEP The TCA precipitation minimizes protease reactivation.

7. Vortex and incubate on ice for 30 minutes.

8. Centrifuge at $11,300 \mathrm{~g}$ for $15 \mathrm{~min}$ at $4{ }^{\circ} \mathrm{C}$. Discard the supernatant.

9. Wash the protein pellets with $1 \mathrm{~mL}$ of acetone. Vortex thoroughly and centrifuge at $11,300 \mathrm{~g}$ for $15 \mathrm{~min}$ at $4{ }^{\circ} \mathrm{C}$.

- PAUSE POINT While in acetone, samples can be stored at $-20^{\circ} \mathrm{C}$ for some days.

10. Discard the supernatant. Spin down for 1-2 sec and remove the remaining acetone.

11. Dry protein pellets at $37^{\circ} \mathrm{C}(2-5 \mathrm{~min})$.

$\triangle$ CRITICAL STEP Acetone interferes with protein solubilization in Laemmli sample buffer; ensure it has evaporated completely.

SDS-PAGE/Western-blot/Autoradiography • TIIMIING 3-4 hours for SDS-PAGE/

Western-blot plus 12-16 hours for autoradiography

12. Prepare samples for SDS-PAGE analysis. Note that two different SDS-containing sample buffers are used here. Whenever the aim of the experiment is to detect monoubiquitinated PEX5 use the modified non-reducing Laemmli sample buffer described in Option A. For all other situations use the classical reducing Laemmli sample buffer and the procedure described in Option B.

A) Protein solubilization with modified Laemmli sample buffer (non-reducing):

i) Resuspend protein pellets (from organelle and soluble fractions) in Laemmli sample buffer 1x lacking reducing agents and containing instead $10 \mathrm{mM}$ NEM.

$\triangle$ CRITICAL STEP To detect monoubiquitinated PEX5, thiol-based reducing agents (such as DTT or $\beta$-mercaptoethanol) cannot be added to the loading sample buffer, otherwise the thioester bond that links ubiquitin to cysteine 11 of PEX5 will be disrupted.

ii) Incubate samples for $30 \mathrm{~min}$ at $45^{\circ} \mathrm{C}$ with shaking.

iii) Spin down for $30 \mathrm{sec}$ at $11,300 \mathrm{~g}$ to collect samples at the bottom of the tube.

B) Protein solubilization with Laemmli sample buffer (reducing):

vi) Resuspend protein pellets in Laemmli sample buffer $1 \mathrm{x}$ containing $100 \mathrm{mM}$ DTT.

vii) Incubate samples for $10 \mathrm{~min}$ at $65^{\circ} \mathrm{C}$ and then $5 \mathrm{~min}$ at $90{ }^{\circ} \mathrm{C}$ with shaking. 
viii) Spin down for $30 \mathrm{sec}$ at $11,300 \mathrm{~g}$ to collect samples at the bottom of the tube.

13. Load protein samples onto an SDS-gel. For experiments containing only organelle pellets load the equivalent to $500 \mu \mathrm{g}$ of PNS protein per lane. When analyzing equivalent amounts of both cytosolic supernatants and organelle pellets load the material obtained from 80-125 $\mu \mathrm{g}$ of PNS protein per lane, to avoid gel overloading problems. Also, load one lane with molecular-weight standards and another with the original ${ }^{35} \mathrm{~S}$-labeled protein prepared in either classical or modified Laemmli sample buffer, as appropriate (e.g., 5-10\% of the amount used in each assay). SDS-gels can be run under standard conditions but, when the aim is to detect the labile monoubiquitinated PEX5 species, better results are obtained when gels are run in a cold room $\left(4^{\circ} \mathrm{C}\right)$.

14. Transfer the proteins from the gel onto a nitrocellulose membrane (Western-blot) using a standard semi-dry apparatus.

15. Stain the membrane with the Ponceau $\mathrm{S}$ solution for $1 \mathrm{~min}$. Destain with a large volume of water for a few seconds until the membrane (but not the protein bands) is almost white.

! CAUTION Contains TCA. Very corrosive. Handle with care.

$\triangle$ CRITICAL STEP Check that protein loadings were as planned and that samples were not degraded during processing/analysis.

? TROUBLESHOOTING

16. Place the Ponceau S-stained membrane in a completely transparent plastic cover (e.g., a transparent sheet protector) and make a digital record of it using a standard computer scanner or any other high-resolution device.

17. Mark the membrane with small radioactive ink dots alongside the molecular-weight markers. Dry the membrane using a hair dryer.

$\triangle$ CRITICAL STEP The radioactive dye will help aligning the film with the Ponceau S-stained membrane. Dry slowly, keeping the hair dryer $10-20 \mathrm{~cm}$ away from the nitrocellulose membrane. Nitrocellulose is an explosive and it will burn completely if heated too much! On the other hand, note that if the membrane is not completely dried it will stick to the x-ray film.

18. Expose the membrane to an x-ray film overnight in an exposure cassette.

19. On the next day, develop the film.

? TROUBLESHOOTING

20. Analyze results. 


\section{? TROUBLESHOOTING}

\section{- TIMING}

STEP 1-11, in vitro import(/export) protocol: 3-5 hours.

STEP 12-20, SDS-PAGE/Western-blot/Autoradiography: 3-4 hours for SDS-PAGE/ Western-blot plus 12-16 hours for autoradiography.

Box 1, preparation of rat/mouse liver post-nuclear supernatant (PNS): $\sim 1$ hour.

Box 2, synthesis of radiolabeled proteins: $\sim 2$ hours for in vitro synthesis plus 3-6 hours for SDS-PAGE/Western-blot/autoradiography analysis.

Box 3, expression and purification of recombinant proteins: 4-5 days.

\section{TROUBLESHOOTING}

\begin{tabular}{|c|c|c|c|}
\hline Step & Problem & Possible reason & Possible solution \\
\hline 15 & $\begin{array}{l}\text { Disappearance of high } \\
\text { molecular weight protein } \\
\text { bands in one or several lanes } \\
\text { in the Ponceau S-stained } \\
\text { membrane. }\end{array}$ & $\begin{array}{l}\text { Protease was not properly } \\
\text { inactivated or became active } \\
\text { during sample processing/SDS- } \\
\text { PAGE analysis. }\end{array}$ & $\begin{array}{l}\text { Make sure the protease in the stock solution } \\
\text { is completely solubilized. } \\
\text { Use a fresh stock of PMSF. } \\
\text { Be sure to remove as much supernatant as } \\
\text { possible after step 6-B-iv. } \\
\text { If the reporter protein is highly susceptible } \\
\text { to protease treatment, the protease } \\
\text { concentration in step 6-B-i may be } \\
\text { decreased, or a less aggressive protease may } \\
\text { be used. For instance, reactivation of } \\
\text { trypsin is very rare whereas proteinase K } \\
\text { reactivates with some frequency. }\end{array}$ \\
\hline 19 & $\begin{array}{l}\text { The membrane is glued to the } \\
\text { x-ray film. }\end{array}$ & $\begin{array}{l}\text { The membrane was not properly } \\
\text { dried. }\end{array}$ & $\begin{array}{l}\text { Do not attempt to detach the membrane } \\
\text { from the film. Just immerse the film and } \\
\text { membrane in a tray with water and shake } \\
\text { gently until the two separate. Stain, dry, and } \\
\text { expose the membrane to a new x-ray film. }\end{array}$ \\
\hline \multirow[t]{2}{*}{20} & \multirow[t]{2}{*}{$\begin{array}{l}\text { Low import yields of the } \\
\text { PTS1 reporter protein. }\end{array}$} & $\begin{array}{l}\text { Not enough recombinant PEX5 } \\
\text { was added during the pre- } \\
\text { incubation step or to the import } \\
\text { reaction. }\end{array}$ & $\begin{array}{l}\text { Titrate the amount of recombinant PEX5 } \\
\text { needed for optimum import yields. } \\
\text { Different cargoes have different } \\
\text { requirements. }\end{array}$ \\
\hline & & $\begin{array}{l}\text { The reporter protein has a weak } \\
\text { PTS1. }\end{array}$ & $\begin{array}{l}\text { Proteins harbouring a weak PTS1 are not } \\
\text { imported in this in vitro system. Use other } \\
\text { systems (e.g., see Ref. }{ }^{35-37} \text { ). Alternatively, } \\
\text { mutating the PTS1 into a stronger version } \\
\text { might increase its in vitro import yield. }\end{array}$ \\
\hline 20 & $\begin{array}{l}\text { A radioactive band migrating } \\
\text { a few } \mathrm{kDa} \text { above }{ }^{35} \mathrm{~S} \text {-labeled } \\
\text { PEX5 is observed in the input }\end{array}$ & $\begin{array}{l}\text { This band probably represents a } \\
\text { DTT-sensitive oxidative adduct } \\
\text { between radiolabeled PEX5 and }\end{array}$ & $\begin{array}{l}\text { Pre-incubate the rabbit reticulocyte lysate } \\
\text { containing radiolabeled PEX } 5 \text { with } 0.5 \mathrm{mM} \\
\text { DTT for } 5 \mathrm{~min} \text { on ice before the dilution }\end{array}$ \\
\hline
\end{tabular}




\begin{tabular}{|l|l|l|l|}
\hline & $\begin{array}{l}\text { sample upon SDS-PAGE } \\
\text { under } \\
\text { conditions. }\end{array}$ & $\begin{array}{l}\text { the abundant hemoglobin protein } \\
\text { from the lysate. }\end{array}$ & step (step 1). \\
\hline 20 & $\begin{array}{l}\text { NDPEX14 did not inhibit } \\
\text { import of the reporter PTS1 } \\
\text { protein. }\end{array}$ & $\begin{array}{l}\text { The PTS1 protein oligomerized } \\
\text { during synthesis and is } \\
\text { intrinsically protease-resistant. A } \\
\text { fraction of the reporter protein is } \\
\text { thus recovered in the protease- } \\
\text { treated organelle pellets. }\end{array}$ & $\begin{array}{l}\text { Synthesise a new batch of reporter protein } \\
\text { in presence of recombinant PEX5. } \\
\text { Alternatively, decrease the incubation time } \\
\text { of the protein synthesis step to 30-60 min. } \\
\text { See } 2 .\end{array}$ \\
\hline
\end{tabular}

\section{ANTICIPATED RESULTS}

The protocol detailed above describes the basic configuration of organelle-based in vitro import assays using as reporter proteins either radiolabeled peroxisomal matrix proteins (containing a PTS1 or PTS2) or the corresponding shuttling receptors (PEX5 and PEX5L.PEX7). All assays include a suitable negative control sample to attest for the specificity of the experiments.

Fig. 2a shows a PEX5-centered in vitro import assay performed in presence ubiquitin aldehyde (Ubal; see Table 1) and either ATP or the non-hydrolysable analogue AMP-PNP. The experiment clearly shows that in the presence of AMP-PNP only organelle-associated PEX5 is monoubiquitinated. Substituting ATP for AMP-PNP leads to the appearance of monoubiquitinated PEX5 in the cytosolic fraction of the assays, reflecting export of DTMembedded Ub-PEX5 into the cytosol, a process catalysed by the ATP-dependent mechanoenzymes PEX1/PEX6. The relationship between organelle-associated Ub-PEX5 and soluble Ub-PEX5 could be easily confirmed by performing a two-step import/export assay, in which organelles from an AMP-PNP-containing assay are isolated by centrifugation, resuspended in import buffer, and incubated in the presence of ATP ${ }^{30}$. Fig 2b shows that PEX5 is indeed covalently modified by an ubiquitin molecule - addition of the ubiquitin analog GST-Ub to the assay increases the molecular mass of the modified PEX5 species by $c a$. $30 \mathrm{kDa}$, the molecular mass of GST. Finally, the fact that monoubiquitinated PEX5 is no longer detected when samples are treated with thiolcontaining reagents before SDS-PAGE analysis indicates that the ubiquitin is linked to PEX5 through a thioester bond. Identical in vitro assays performed with ${ }^{35} \mathrm{~S}$-labeled PEX5(C11K) and PEX5(C11A) would show that cysteine 11 of PEX5 is the ubiquitinated residue ${ }^{23}$.

Fig. 2c shows the typical results of the PTS1-centered in vitro assay using ${ }^{35}$ S-labeled SCPX as the reporter protein. Note how import of SCPx is almost completely dependent on the pre-incubation step with recombinant PEX5 - a chemically identical assay, but in which the pre-incubation step was omitted, shows essentially no protease-protected SCPx (compare lanes 2 and 3). To demonstrate that the protease-resistant radiolabeled SCPx reflects authentic peroxisomal import, one control reaction was performed in the presence of 
NDPEX14. This recombinant protein binds to PEX5 and inhibits the PEX5-mediated import of SCPx (compare lane 4 with lane 5). The complete protease-treated import reaction (i.e., the organelle suspension obtained after step 6-B-ii of the protocol) can also be subjected to nycodenz gradient centrifugation to demonstrate that the reporter protein cosediments with pure peroxisomes ${ }^{26,27}$.

Fig. $2 \mathrm{~d}$ shows the result of an in vitro import assay where both ${ }^{35} \mathrm{~S}$-pre-thiolase, a PTS2 protein, and ${ }^{35} \mathrm{~S}-\mathrm{PEX} 7$ were used as reporter proteins. Note the marked increase in yields when recombinant $\triangle \mathrm{C} 1 \mathrm{PEX} 5 \mathrm{~L}$ is added to the assays (compare lanes 1 and 3 ). Note also that a fraction of protease-protected ${ }^{35} \mathrm{~S}$-labeled pre-thiolase was converted into a faster migrating species (lanes 3 and 5). This reflects processing of the precursor protein into its mature form, a relatively fast event in vivo and in vitro ${ }^{26,42}$. Some PTS1 proteins (e.g., acyl-CoA oxidase 1 and SCPx) also undergo processing at the peroxisome matrix. However, these events are much slower, requiring many hours to be detected in vivo ${ }^{42-44}$. Thus, they are barely detected in in vitro assays.

The amount of organelle-associated protease-resistant ${ }^{35} \mathrm{~S}$-labeled PEX7 in these assays can be further increased by supplementing the import reaction with a recombinant PTS2 protein, in casu prePHYH (Fig 2d, compare lanes 3 and 4). As expected, in the presence of recombinant prePHYH, but not mature PHYH (matPHYH) lacking the PTS2, proteaseresistant ${ }^{35} \mathrm{~S}$-pre-thiolase is no longer detected (Fig. 2d, compare lanes 4 and 5), reflecting competition with the more abundant recombinant PTS2 protein. Again, NDPEX14 completely blocks entry of ${ }^{35} \mathrm{~S}-\mathrm{PEX} 7$ into the organelle (compare lane 6 with lane 4 ). In the assay shown in lane 2 , recombinant $\triangle \mathrm{C} 1 \mathrm{PEX} 5 \mathrm{~S}$ was used instead of $\triangle \mathrm{C} 1 \mathrm{PEX} 5 \mathrm{~L}$. These two recombinant proteins are almost identical, except for the fact that $\triangle \mathrm{C} 1 \mathrm{PEX} 5 \mathrm{~S}$ lacks an internal 37 amino acid domain present in $\triangle \mathrm{C} 1 \mathrm{PEX} 5 \mathrm{~L}$, which contains the PEX7-bindind domain. As expected, neither reporter protein acquired a protease-protected status under these conditions, in agreement with the fact that only the large isoform of PEX5 is competent in the PTS2-mediated protein import pathway 45 .

\section{FIGURE LEGENDS}

\section{Figure 1. The PEX5-mediated protein import pathway.}

a) Peroxisomal matrix proteins possess within their polypeptide chain one of two peroxisomal targeting signals: a PTS1 or a PTS2. The PTS1 is a small C-terminal peptide, usually ending in S-K-L ${ }^{16}$. The PTS2 is a degenerated nonapeptide present at the N-termini of a few peroxisomal proteins, which contrary to the PTS 1 is cleaved upon import ${ }^{46,47}$. The PEX5 transcript undergoes alternative splicing yielding a small and a large isoform, PEX5S and PEX5L, respectively ${ }^{45}$. The first does not interact with PEX7/PTS2 and thus only participates in the PTS1-mediated protein import pathway; the second transports both types of cargo proteins to the peroxisome ${ }^{45,48}$. b) The mechanism of the PIM. Cytosolic PEX5 (Stage 0 PEX5) forms a complex with newly synthesised matrix proteins (CP; Stage 1a). 
The receptor-cargo complex then docks at the peroxisomal membrane docking/translocation machinery (DTM; Stage 1b) where it becomes inserted (Stage 2) resulting in the release of the cargo protein into the organelle matrix. PEX5 is then monoubiquitinated at cysteine 11 (Stage 3a), recognized by the receptor export module (REM; Stage 3b) and extracted in an ATP-dependent step yielding cytosolic monoubiquitinated PEX5 (Stage 4). Finally, the ubiquitin moiety is removed probably by a combination of enzymatic (USP9X) and non-enzymatic events (e.g., by nucleophiles such as glutathione; GSH) yielding free PEX5 (Stage 0). PEX7, the co-receptor for PTS2proteins, remains bound to PEX5 during most of the steps of the PTS2-mediated protein import pathway. For simplicity, PEX7 is not shown in the figure. Several strategies/tools to block this pathway at different steps (shown in red; $\otimes$ ) are also indicated. Abbreviations used: C11S/A, PEX5 protein mutated version with the conserved cysteine 11 replaced by a serine or an alanine residue; $\mathrm{CP}$, cargo protein; cyt, cytosol; DTM, docking/translocation module; E1, ubiquitin-activating enzyme; E2, ubiquitin-conjugating enzyme; GSH, glutathione; GST-Ub, glutathione S-transferase ubiquitin fusion protein; IAA, iodoacetamide; NDPEX14, recombinant protein comprising the soluble N-terminal domain of PEX14; REM, receptor export module; mat, peroxisomal matrix; TPRs, recombinant protein comprising only the PEX5 tetratricopeptide repeats domain; Ub, ubiquitin; Ubal, ubiquitin aldehyde.

\section{Figure 2. Receptor- and cargo-centered in vitro import assays:}

a) PEX5-centered in vitro import assay: export of monoubiquitinated PEX5 is an ATPdependent step. Radiolabeled PEX5L was subjected to in vitro import reactions in the presence of Ubal and either ATP or AMP-PNP. After incubation, NEM-treated reactions were centrifuged to separate organelles (P) from supernatants (S). Samples (derived from $100 \mu \mathrm{g}$ of PNS protein) were then subjected to SDS-PAGE under nonreducing conditions. The membrane was probed with anti-PEX14 (a peroxisomal membrane protein) and anti- $\alpha$ Tubulin (a cytosolic protein). Lane I, 10\% of the radiolabeled protein used in the total reactions. The Ponceau S-stained membrane is also shown. b) PEX5 is monoubiquitinated at a cysteine residue. Radiolabeled PEX5L was incubated with a PNS in import buffer supplemented with AMP-PNP and either ubiquitin (Ub) or GST-ubiquitin (GST-Ub). NEM-treated organelles were then isolated and analysed under nonreducing (-DTT) and reducing conditions (+DTT) by SDS-PAGE/Western-blot/autoradiography. Lane I, 25\% of the radiolabeled protein used in each assay. The Ponceau S-stained membrane is shown. c) In vitro import of radiolabeled SCPx. Radiolabeled SCPx was subjected to in vitro import reactions in the presence of ATP and in the absence (lane 1) or presence of recombinant PEX5L (lanes 2-5). PEX5L was either added after the final reaction is assembled (lane 2) or pre-incubated with radiolabeled SCPx included in the lysate mix (lanes 3-5). Where indicated, NDPEX14 or PEX19 (a protein involved in a different aspect of peroxisome biogenesis ${ }^{49}$ ) were included in the reactions (lanes 4 and 5 , respectively). PK-treated organelles were subjected to SDS-PAGE/Western-blot/autoradiography. Lanes $\mathrm{I}_{1}$ and $\mathrm{I}_{2}$, 
$10 \%$ of the radiolabeled protein used in the assays shown in lanes 1 and 2, and lanes 3-5, respectively. To assess protein loadings, the membrane was probed with anti-Catalase (a peroxisomal matrix protein). The Ponceau S-stained membrane is also shown. d) In vitro import of radiolabeled PEX7 and pre-thiolase. Radiolabeled PEX7 and pre-thiolase (preThiol) were subjected to in vitro import reactions in the absence (-) or presence (+) of the indicated recombinant proteins. Pronase-treated organelles were then analysed by SDSPAGE/Western-blot/autoradiography. MatThiol, mature form of thiolase. Lane I, 5\% of the radiolabeled proteins used in the assays. To assess protein loadings, the membrane was probed with anti-Catalase. The Ponceau S-stained membrane is also shown.

\section{TABLES}

Table 1. Tools/strategies to stimulate or block the peroxisomal protein import pathway.

\begin{tabular}{|c|c|}
\hline PEX5L & $\begin{array}{l}\text { Recombinant full length PEX5L. Generally used to stimulate import of PTS1- } \\
\text { containing cargo proteins }{ }^{14,27} \text {. Concentration in the assay should be titrated for } \\
\text { each PTS1 reporter cargo protein. Pre-incubation of recombinant PEX5 with } \\
\text { some PTS1 proteins dramatically increases their import yields. }\end{array}$ \\
\hline$\triangle \mathrm{C1PEX5L}$ & $\begin{array}{l}\text { A protein comprising the first } 324 \text { amino acid residues of PEX5L. It contains } \\
\text { all the domains necessary to interact with PEX7/PTS } 2 \text { and the DTM, but it does } \\
\text { not interact efficiently with PTS } 1 \text { proteins }{ }^{19,50} \text {. Supplementing import reactions } \\
\text { with recombinant } \triangle \mathrm{C} 1 \mathrm{PEX} 5 \mathrm{~L} \text { boosts the PTS2-mediated import pathway. It } \\
\text { bypasses competition with endogenous PTS1-containing proteins }{ }^{3,26} \text {. }\end{array}$ \\
\hline PEX5L(N526K) & $\begin{array}{l}\text { Full length PEX5L containing the mutation N526K. This protein cannot bind } \\
\text { PTS1 proteins efficiently, but like } \triangle \mathrm{C} 1 \mathrm{PEX} 5 \mathrm{~L} \text {, is competent in the PTS2- } \\
\text { mediated protein import pathway } 51,52 \text {. Supplementing import reactions with } \\
\text { recombinant PEX5L(N526K) boosts the PTS2-mediated import }{ }^{3,26} \text {. }\end{array}$ \\
\hline TPRs & $\begin{array}{l}\text { C-terminal half of PEX5 (amino acids } 315-639 \text { of PEX5L) comprising its } \\
\text { tetratricopeptide repeats domain which is necessary for efficient PTS1 cargo } \\
\text { binding }{ }^{52} \text {. It is import incompetent because it lacks the N-terminal domains } \\
\text { required for interaction with the DTM }{ }^{53} \text {. The recombinant protein is used to } \\
\text { sequester both }{ }^{35} \text { S-labeled and endogenous PTS1-containing proteins. Thus, it } \\
\text { blocks both import of PTS1 reporter proteins and the PTS1-mediated insertion } \\
\text { of }{ }^{35} \text { S-labeled PEX5 into the DTM }{ }^{19,27,54} \text {. }\end{array}$ \\
\hline $\begin{array}{l}\operatorname{PEX5L}(\mathrm{C11S}) / \\
\operatorname{PEX5L}(\mathrm{C11A})\end{array}$ & $\begin{array}{l}\text { Full length PEX5L in which cysteine } 11 \text { was replaced by a serine or an alanine, } \\
\text { respectively. These mutant PEX5L species can promote one cycle of protein } \\
\text { transport to the peroxisome matrix. However, they are export-incompetent } \\
\text { because they cannot be monoubiquitinated efficiently. Thus, they accumulate at }\end{array}$ \\
\hline
\end{tabular}




\begin{tabular}{|c|c|}
\hline & the DTM ${ }^{21,23}$. \\
\hline PEX5L(C11K) & $\begin{array}{l}\text { Full length PEX5L in which cysteine } 11 \text { was replaced by lysine. This protein is } \\
\text { functional in both the import and export steps. Monoubiquitination at the lysine } \\
\text { residue yields an isopeptide bond which is much more stable than the thioester } \\
\text { bond linking ubiquitin to the cysteine residue in wildtype PEX5L. Thus, SDS- } \\
\text { PAGE can be performed under reducing conditions }{ }^{23} \text {. }\end{array}$ \\
\hline PEX5L-EGFP & $\begin{array}{l}\text { Full length PEX5L with a C-terminal EGFP tag. This bulky PEX5 fusion } \\
\text { protein becomes inserted into the DTM and is monoubiquitinated. However, } \\
\text { although monoubiquitinated PEX5L-EGFP is recognized by the REM, it is not } \\
\text { efficiently released into the cytosol. A partially dislocated species accumulates } \\
\text { in in vitro assays } 55 \text {. }\end{array}$ \\
\hline NDPEX14 & $\begin{array}{l}\text { Recombinant protein comprising the first } 80 \text { amino acid residues of human } \\
\text { PEX14, a component of the DTM }{ }^{56} \text {. This domain binds with high affinity the } \\
\text { diaromatic motifs present in the N-terminal half of PEX5, which are essential } \\
\text { for PEX5 function }{ }^{57,58} \text {. Used to inhibit import of all cargoes and insertion of } \\
\text { the corresponding receptors into the DTM }{ }^{3,27} \text {. }\end{array}$ \\
\hline PrePHYH & $\begin{array}{l}\text { Recombinant precursor of phytanoyl-CoA hydroxylase, a PTS } 2 \text { protein used to } \\
\text { stimulate targeting of PEX7 to the peroxisome }{ }^{3,13} \text {. }\end{array}$ \\
\hline $\begin{array}{l}\text { Import at } \\
<16^{\circ} \mathrm{C}\end{array}$ & $\begin{array}{l}\text { PEX5-cargo protein complexes dock at the DTM but insertion of PEX5 into the } \\
\text { DTM and cargo translocation are inhibited }{ }^{27} \text {. }\end{array}$ \\
\hline $\begin{array}{l}\text { Import at } \\
16<\mathrm{T}<26^{\circ} \mathrm{C}\end{array}$ & $\begin{array}{l}\text { Insertion of PEX5 into the DTM and cargo-translocation occur at these } \\
\text { temperatures, but the ubiquitin conjugating cascade is compromised. Thus, } \\
\text { PEX5 export is greatly diminished and thus more PEX5 is detected at the DTM } \\
27,59 \text {. }\end{array}$ \\
\hline Apyrase & $\begin{array}{l}\text { Apyrase is an ATP-diphosphatase that hydrolyses ATP and other NTPs }{ }^{60} \text {, } \\
\text { effectively blocking PEX5 monoubiquitination and export }{ }^{26} \text {. PEX5 will } \\
\text { accumulate at the DTM. Pre-treat both the lysate and the ATP-primed PNS mix } \\
\text { with } 5-20 \mathrm{U} / \mathrm{mL} \text { for } 2 \mathrm{~min} \text { at } 37^{\circ} \mathrm{C} \text {. }\end{array}$ \\
\hline Iodoacetamide & $\begin{array}{l}\text { Iodoacetamide is an alkylating agent that modifies cysteine } 11 \text { of PEX5 } 54 \\
\text { Alkylated PEX } 5 \text { cannot be monoubiquitinated and, consequently, the receptor } \\
\text { accumulates at the DTM. }\end{array}$ \\
\hline $\begin{array}{l}\text { ATP } \gamma \mathrm{S} / \\
\text { AMP-PNP }\end{array}$ & $\begin{array}{l}\text { Non-hydrolysable ATP analogues such as ATP } \gamma \text { S or AMP-PNP are excellent } \\
\text { substrates for the ubiquitin activating enzyme } 61 \text {. Thus, PEX5 } \\
\text { monoubiquitination occurs normally in the presence of these nucleotides. } \\
\text { However, they inhibit the AAA ATPases that comprise the REM and thus Ub- } \\
\text { PEX5 becomes trapped at the DTM }{ }^{21,30} \text {. }\end{array}$ \\
\hline
\end{tabular}




\begin{tabular}{|l|l|}
\hline GST-Ub & $\begin{array}{l}\text { GST-Ub is a recombinant fusion protein comprising glutathione S-transferase } \\
\text { and ubiquitin. This molecule is efficiently used by the ubiquitin-conjugating } \\
\text { cascade and can be coupled to cysteine } 11 \text { of PEX5. However, it acts as a } \\
\text { dominant-negative analogue of ubiquitin, completely blocking export of } \\
\text { monoubiquitinated PEX5 from the DTM }{ }^{21} .\end{array}$ \\
\hline Ubal & $\begin{array}{l}\text { Ubiquitin aldehyde is an ubiquitin in which the C-terminal glycine carboxyl } \\
\text { group was synthetically modified to an aldehyde }{ }^{62} \text { It is a potent and highly } \\
\text { specific inhibitor of most deubiquitinases including USP9X, the enzyme that } \\
\text { acts on cytosolic Ub-PEX5 (note that DTM-embedded Ub-PEX5 is not a } \\
\text { substrate for deubiquitinases) }\end{array}$ \\
\hline
\end{tabular}

Table 2. PEX5, PEX7, PTS2, or PTS1 lysate mix for 2 reactions (Rx).

\begin{tabular}{|c|c|c|c|}
\hline & & Reporter & rotein \\
\hline & & PEX5, PEX7, pre-thiolase & SCPx* \\
\hline Components & $\begin{array}{l}\text { Amount/ } \\
\text { concentration }\end{array}$ & $\mathbf{V}(\boldsymbol{\mu L})$ & $\mathbf{V}(\mu \mathbf{L})$ \\
\hline Import buffer $6 x$ & $1 \mathrm{x}$ & 3.3 & 3.3 \\
\hline $\mathrm{ddH}_{2} \mathrm{O}$ & to $20 \mu \mathrm{L}$ & 14.7 & 13.7 \\
\hline
\end{tabular}

After mixing these components, add:

\begin{tabular}{l|l|l|l}
\hline PEX5L $20 \mathrm{ng} / \mu \mathrm{L}$ & $20 \mathrm{ng}$ & - & 1 \\
${ }^{35}$ S-Lysate & $2 \mu \mathrm{L}$ & 2 & 2 \\
\hline Final Volume & & 20 & 20
\end{tabular}

* For SCPx, incubate the lysate mix for 15 min at $37^{\circ} \mathrm{C}$.

Table 3. PNS mix for 2 reactions (Rx).

\begin{tabular}{l|l|l} 
Components & $\begin{array}{l}\text { Amount/ } \\
\text { concentration }\end{array}$ & $\mathbf{V}(\boldsymbol{\mu L})$ \\
\hline Import buffer 6x & $1 \mathrm{x}$ & 16.7 \\
$\mathrm{ddH}_{2} \mathrm{O}$ & to $100 \mu \mathrm{L}$ & $81.9-x$ \\
$\mathrm{ATP} 0.1 \mathrm{M}$ & $0.4 \mathrm{mM}$ & 0.4 \\
$\mathrm{E}-640.4 \mathrm{mg} / \mathrm{mL}$ & $4 \mu \mathrm{g} / \mathrm{mL}$ & 1 \\
\hline
\end{tabular}

After mixing these components, add:

\begin{tabular}{l|l|l}
\hline PNS $(40-90 \mu \mathrm{g} / \mu \mathrm{L})$ & $1 \mathrm{mg}$ & $x$ \\
\hline Final Volume & & 100
\end{tabular}

Table 4. Receptor- and cargo protein-centered in vitro reaction assembly. 


\begin{tabular}{|c|c|c|c|c|c|c|c|c|c|}
\hline & & \multicolumn{8}{|c|}{ Reporter Protein } \\
\hline & & \multicolumn{2}{|c|}{ PEX5 } & \multicolumn{2}{|c|}{ PEX7 } & \multicolumn{2}{|c|}{ SCPx } & \multicolumn{2}{|c|}{ pre-thiolase } \\
\hline & & ATP & AMP-PNP & - & +NDP14* & - & +NDP14* & - & +NDP14* \\
\hline Components & $\begin{array}{l}\text { Amount/ } \\
\text { concentration }\end{array}$ & $\mathbf{V}(\boldsymbol{\mu} \mathbf{L})$ & $\mathbf{V}(\boldsymbol{\mu} \mathbf{L})$ & $\mathbf{V}(\boldsymbol{\mu} \mathbf{L})$ & $\mathbf{V}(\boldsymbol{\mu} \mathbf{L})$ & $\mathbf{V}(\boldsymbol{\mu} \mathbf{L})$ & $\mathbf{V}(\boldsymbol{\mu} \mathbf{L})$ & $\mathbf{V}(\boldsymbol{\mu} \mathbf{L})$ & $\mathbf{V}(\boldsymbol{\mu} \mathbf{L})$ \\
\hline Import buffer $6 x$ & $1 \mathrm{x}$ & 6.7 & 6.7 & 6.7 & 6.7 & 6.7 & 6.7 & 6.7 & 6.7 \\
\hline $\mathrm{ddH}_{2} \mathrm{O}$ & & 29.3 & 29.3 & 25.9 & 25.9 & 27.5 & 27.5 & 26.1 & 26.1 \\
\hline ATP $0.1 \mathrm{M}$ & $3 \mathrm{mM}$ & 3 & - & 3 & 3 & 3 & 3 & 3 & 3 \\
\hline AMP-PNP $0.1 \mathrm{M}$ & $3 \mathrm{mM}$ & - & 3 & - & - & - & - & - & - \\
\hline GSH $0.1 \mathrm{M}$ & $2 \mathrm{mM}$ & - & - & 2 & 2 & 2 & 2 & 2 & 2 \\
\hline
\end{tabular}

After mixing these components, add:

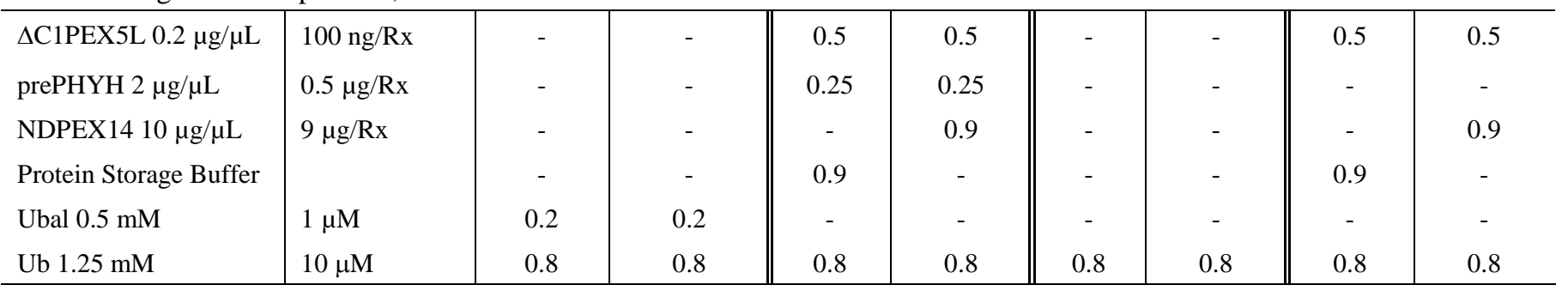

After mixing these components, add:

\begin{tabular}{|c|c|c|c|c|c|c|c|c|}
\hline PNS mix & 50 & 50 & 50 & 50 & 50 & 50 & 50 & 50 \\
\hline \multicolumn{9}{|c|}{ Incubate for $1 \mathrm{~min}$ at $37^{\circ} \mathrm{C}$ and then add: } \\
\hline
\end{tabular}

* NDP14 - recombinant NDPEX14

\section{Box 1}

Preparation of rat/mouse liver post-nuclear supernatant (PNS) $\bullet$ TIMIING $\sim 1$ hour

$\triangle$ CRITICAL STEP Ensure that all materials and solutions are ice-cold.

1. Euthanize one rat/mouse and immediately open the abdominal cavity using scissors.

! CAUTION Experiments using rodents must conform to national and institutional regulations.

2. Collect the liver and wash it with ice-cold SEM buffer. Blot it briefly onto paper towels, and weight it.

3. Put the liver in a petri dish standing on ice and cut it into small pieces using scissors. 
4. Transfer the liver pieces to the ice-cold Potter-Elvehjem glass tube and add a total of 4 $\mathrm{mL}$ of ice-cold SEM buffer supplemented with 1:200 (v/v) of E-64 stock solution per gram of liver.

5. Homogenize the liver with 1-2 strokes of the Teflon pestle working at $600 \mathrm{rpm}$.

$\triangle$ CRITICAL STEP Only 1-2 strokes are used to minimize organelle disruption.

6. Transfer the total homogenate to a centrifuge tube (e.g., for rotor SS-34) and centrifuge at $600 \mathrm{~g}$ for $10 \mathrm{~min}$ at $4{ }^{\circ} \mathrm{C}$. Transfer the supernatant to a clean centrifuge tube precooled on ice and repeat the centrifugation step. The supernatant of this last centrifugation is the PNS.

7. Snap freeze single-use aliquots (e.g., 100-200 $\mu \mathrm{L}$ in microtubes) in liquid $\mathrm{N}_{2}$ and store at $-70{ }^{\circ} \mathrm{C}$.

! CAUTION When handling liquid nitrogen, always use personal protective equipment including insulated leather gloves and eye and face protection.

a PAUSE POINT When stored at $-70{ }^{\circ} \mathrm{C}$, the PNS remains active for many months.

8. Determine protein concentration of the PNS (e.g., using the Bradford method). It should be around 40-90 $\mu \mathrm{g} / \mu \mathrm{L}$.

\section{Box 2}

Synthesis of radiolabeled proteins $\bullet$ TIMIING $\sim 2$ hours for in vitro synthesis plus 3-6 hours for SDS-PAGE/Western-blot/autoradiography analysis

! CAUTION Wear gloves and follow appropriate laboratory procedures to handle radioactive material.

$\triangle$ CRITICAL STEP To avoid RNase contamination, microtubes and pipette tips should be RNase-free. Reserve a new box/package of these materials for this purpose and always handle them wearing clean gloves.

1. Assemble a $50 \mu \mathrm{L} \mathrm{TNT}^{\circledR} \mathrm{T} 7$ Quick Coupled Transcription/Translation reaction according to the manufacturer instructions and synthesise the ${ }^{35} \mathrm{~S}$-labeled reporter protein.

$\triangle$ CRITICAL STEP Some PTS1 proteins (e.g., catalase, acyl-CoA oxidase 1, and urate oxidase) have been shown to homo-oligomerize during in vitro synthesis yielding protease-resistant species. Addition of recombinant PEX5L $(0.1-1 \mu \mathrm{M})$ at the beginning of the synthesis reaction prevents this, and yields soluble, protease-sensitive monomeric species, which, in at least two cases, are much better import substrates than the corresponding oligomeric forms $\left({ }^{14,50}\right)$. Alternatively, decrease the suggested time 
of protein synthesis from 90 min to 30-60 min (homo-oligomerization is concentrationand time-dependent).

2. Aliquot the rabbit reticulocyte lysate containing ${ }^{35} \mathrm{~S}$-labeled reporter protein $($ e.g., $5-\mu \mathrm{L}$ aliquots) and store at $-70{ }^{\circ} \mathrm{C}$. Keep a $0.5 \mu \mathrm{L}$ aliquot to check for correct protein synthesis.

- PAUSE POINT Aliquots can be stored at $-70^{\circ} \mathrm{C}$ for a few months (take into consideration the half-life of ${ }^{35} \mathrm{~S}-87$ days).

3. Add $20 \mu \mathrm{L}$ of Laemmli sample buffer $1 \mathrm{x}$ containing $100 \mathrm{mM}$ DTT to the $0.5 \mu \mathrm{L}$ aliquot saved above, incubate for $5 \mathrm{~min}$ at $90{ }^{\circ} \mathrm{C}$ with shaking and subject to SDSPAGE. Load one lane of the gel with molecular-weight markers.

4. Subject the gel to Western-blot/autoradiography, as described in steps 14-17. Expose the membrane to an x-ray film for 1-2 $\mathrm{h}$, and develop the film. A strong signal corresponding to the ${ }^{35} \mathrm{~S}$-labeled protein should be visible on the autoradiograph.

\section{Box 3}

Expression and purification of recombinant proteins $\bullet$ TIMIING 4-5 days

Several recombinant proteins are required to perform the basic experiments described in the "PROCEDURE" section. These are:

- PEX5L, the large isoform of human PEX5 (histidine-tagged protein; expression plasmid/E. coli strain: pQE30-PEX5/M15 ${ }^{63}$ );

- $\triangle \mathrm{C} 1 \mathrm{PEX} 5 \mathrm{~L}$, a protein comprising the first 324 residues of PEX5L (histidine-tagged protein; expression plasmid/E. coli strain: pET28a- $\Delta$ C1PEX5L/BL21(DE3) ${ }^{33}$ );

- NDPEX14, the N-terminal domain of PEX14, a small recombinant protein comprising the first 80 residues of human PEX14 (histidine-tagged protein; expression plasmid/E. coli strain: pQE30-NDPEX14/XL1 ${ }^{56}$ ); and

- $\quad$ prePHYH, the precursor of human phytanoyl-CoA hydroxylase, a PTS2-containing protein (histidine-tagged protein; expression plasmid/E. coli strain: pQE31prePHYH/M15 ${ }^{41}$ ).

Other recombinant proteins may be produced as well. A useful one for the PEX5-centered in vitro assays is the glutathione S-transferase-ubiquitin fusion protein (GST-Ub), a dominant-negative version of ubiquitin ${ }^{21}$ (see Table 1). This protein is expressed in large amounts in $E$. coli BL21(DE3) and purified using glutathione-sepharose ${ }^{\mathrm{TM}} 4 \mathrm{~B}$ beads (GE Healthcare) ${ }^{64}$. Other recombinant proteins which may be useful in some experiments are: $\triangle \mathrm{C} 1 \mathrm{PEX} 5 \mathrm{~S}$ (equivalent to $\triangle \mathrm{C} 1 \mathrm{PEX} 5 \mathrm{~L}$ but derived from PEX5S; used as a negative control for $\triangle \mathrm{C} 1 \mathrm{PEX} 5 \mathrm{~L} ;{ }^{26}$ ); matPHYH (the mature form of human phytanoyl-CoA hydroxylase; 
used as a negative control for prePHYH; ${ }^{3}$ ); and PEX19 (a peroxin with no role in the PIM, which is sometimes used as negative control for histidine-tagged recombinant proteins; ${ }^{65}$. As the four recombinant proteins listed above, these proteins are also N-terminally histidine-tagged proteins. All are obtained in large amounts from E. coli transformed with the corresponding expression plasmids. With the exception of histidine-tagged PEX5L, which requires an extra chromatography step (e.g., anionic exchange on a Bio-Scale ${ }^{\mathrm{TM}}$ Mini Macro-Prep ${ }^{\circledR}$ High Q column (BioRad) using a 300-800 mM NaCl gradient), all other histidine-tagged recombinant proteins are obtained with adequate purity $(>90 \%)$ after a single immobilized metal-affinity chromatography step using a nickel-nitrilotriacetic acid matrix. Note that all these recombinant proteins are soluble and stable when handled as suggested here. However, if necessary, their monodispersity can be easily assessed by sizeexclusion chromatography or native-PAGE ${ }^{13,50}$. Below, a general protein purification protocol, as well as a buffer exchange procedure for $-70^{\circ} \mathrm{C}$ storage is provided.

1. Inoculate a Petri dish containing LB/Agar plus the appropriate antibiotic(s) with E. coli cells harbouring the relevant expression plasmid. Incubate overnight at $37^{\circ} \mathrm{C}$.

2. Pick a colony and use it to inoculate $25 \mathrm{~mL}$ of $\mathrm{LB}+$ antibiotic(s). Grow this starter culture at $37^{\circ} \mathrm{C}$ with shaking overnight.

3. The following day, dilute the starter culture with $500 \mathrm{~mL}$ of $\mathrm{LB}+$ antibiotic(s). Grow at $37^{\circ} \mathrm{C}$ with shaking for $1.5-2 \mathrm{~h}$, or until $\mathrm{OD}_{600 \mathrm{~nm}}=0.6-0.8$.

4. Induce protein expression with $500 \mu \mathrm{L}$ of $1 \mathrm{M}$ IPTG (1 mM final concentration). Keep at $37^{\circ} \mathrm{C}$ with shaking for $3 \mathrm{~h}$.

5. Centrifuge the culture at $4,500 \mathrm{~g}, 4{ }^{\circ} \mathrm{C}$, for $15 \mathrm{~min}$ to collect cells. Discard the supernatant.

- PAUSE POINT Cell pellets can be stored at $-70{ }^{\circ} \mathrm{C}$ for several months.

6. Resuspend the cell pellet in $30 \mathrm{~mL}$ of Lysis buffer. Use Lysis buffer A for PEX5, $\triangle \mathrm{C} 1 \mathrm{PEX} 5 \mathrm{~L}, \triangle \mathrm{C} 1 \mathrm{PEX} 5 \mathrm{~S}, \mathrm{NDPEX} 14$ and PEX19 and Lysis buffer B for prePHYH and matPHYH.

7. Disrupt cells by sonication for about $4 \mathrm{~min}$ in $10-15 \mathrm{sec}$ pulses (10\% output power, $40 \%$ duty cycle).

$\triangle$ CRITICAL STEP Ensure that the sample is always cold. Keep it on ice and pause sonication as needed.

8. Transfer the E. coli homogenate to a centrifuge tube (e.g., for rotor SS-34) and centrifuge suspension at $12,000 \mathrm{~g}, 4^{\circ} \mathrm{C}$ for $20 \mathrm{~min}$. Collect the clarified lysate and discard the pellet.

9. (Optional additional step) This step is ONLY used for purification of recombinant $\triangle \mathrm{C} 1 \mathrm{PEX} 5 \mathrm{~L}, \triangle \mathrm{C} 1 \mathrm{PEX} 5 \mathrm{~S}$ and PEX19. Put the clarified lysate in a boiling water bath for 
$5 \mathrm{~min}$. Cool on ice for $5 \mathrm{~min}$ and centrifuge suspension at $12,000 \mathrm{~g}, 4^{\circ} \mathrm{C}$ for $20 \mathrm{~min}$. Discard the pellet.

$\triangle$ CRITICAL STEP This will denature and precipitate most $E$. coli proteins leaving the largely natively unfolded $\triangle \mathrm{C} 1 \mathrm{PEX} 5 \mathrm{~L}, \triangle \mathrm{C} 1 \mathrm{PEX} 5 \mathrm{~S}$ and PEX19 recombinant proteins in solution. Thus, sample complexity is dramatically decreased, increasing the purity of the final protein preparation.

10. Add the clarified lysate to $1.5 \mathrm{~mL}$ (bed volume) of HIS-Select ${ }^{\circledR}$ Nickel Affinity Gel beads that were previously washed two times with 3 volumes of $\mathrm{ddH}_{2} \mathrm{O}$ and equilibrated 3 times with 3 volumes of lysis buffer (minus DTT and PMSF). Incubate at $4{ }^{\circ} \mathrm{C}$ for $2 \mathrm{~h}$ with gentle agitation.

11. Spin down for $2 \mathrm{sec}$ at $600 \mathrm{~g}$ to collect beads. Discard the supernatant.

12. Add $15 \mathrm{~mL}$ of Washing buffer A (for PEX5, $\triangle \mathrm{C} 1 \mathrm{PEX} 5 \mathrm{~L}, \triangle \mathrm{C} 1 \mathrm{PEX} 5 \mathrm{~S}$, NDPEX14 and PEX19) or Washing buffer B (for prePHYH and matPHYH) to the beads. Mix by inverting the tube a few times and centrifuge as above. Discard the supernatant. Repeat this step twice.

13. Add $4.5 \mathrm{~mL}$ of Elution buffer and incubate at $4{ }^{\circ} \mathrm{C}$ for $10 \mathrm{~min}$ with agitation. Spin down for $2 \mathrm{sec}$ at $600 \mathrm{~g}$ to collect beads and recover the supernatant (containing the eluted protein). Repeat the elution step and pool the 2 elutions.

14. Using Vivaspin ${ }^{\circledR} 2$ Sample concentrators concentrate the eluted protein to $\sim 200 \mu \mathrm{L}$. Dilute to $2 \mathrm{~mL}$ (final volume) with Protein storage buffer and concentrate again to $\sim 200 \mu \mathrm{L}$. Repeat this step 3 more times.

15. Collect the concentrated protein in an ice-cold microtube, and centrifuge for $20 \mathrm{~min}$ at $11,300 g, 4{ }^{\circ} \mathrm{C}$, to remove any agarose beads. Collect the supernatant and store $10-\mu \mathrm{L}$ aliquots at $-70^{\circ} \mathrm{C}$ after flash freezing in liquid nitrogen.

- PAUSE POINT Aliquots kept at $-70{ }^{\circ} \mathrm{C}$ and not subjected to multiple freeze/thaw cycles are stable up to one year.

16. Estimate protein titer (e.g., Bradford protein assay) and analyze protein purity by SDSPAGE.

\section{COMPETING FINANCIAL INTERESTS}

The authors declare that they have no competing financial interests.

\section{ACKNOWLEDGMENTS}

We thank Marc Fransen, Katholieke Universiteit-Leuven, Belgium, for critical comments on the manuscript and for the plasmid encoding histidine-tagged PEX19. We thank Paul van Veldhoven, Katholieke Universiteit-Leuven, Belgium, and Patricia Maciel, 
Universidade do Minho, Portugal, for the expression plasmids encoding prePHYH and GST-Ub, respectively. This work was financed by FEDER - Fundo Europeu de Desenvolvimento Regional, funds through the COMPETE 2020 - Operacional Programme for Competitiveness and Internationalization (POCI), Portugal 2020, and by Portuguese funds through FCT - Fundação para a Ciência e a Tecnologia/ Ministério da Ciência, Tecnologia e Inovação in the framework of the projects "The molecular mechanism of protein import into peroxisomes" (FCOMP-01-0124-FEDER-019731- PTDC/ BIABCM/118577/2010), "Institute for Research and Innovation in Health Sciences" (POCI-010145-FEDER-007274) and "The molecular mechanisms of peroxisome biogenesis" (PTDC /BEX-BC M/2311/2014), and through Norte 2020 - Programa Operacional Regional do Norte, under the application of the "Porto Neurosciences and Neurologic Disease Research Initiative at i3S (NORTE-01-0145-FEDER-000008)". T.A.R., T.F., A.F.D. and C.P.G. were supported by Fundação para a Ciência e a Tecnologia, Programa Operacional Potencial Humano do QREN and Fundo Social Europeu.

\section{AUTHOR CONTRIBUTIONS STATEMENTS}

T.A.R., T.F., C.P.G., J.E.A. designed research. T.A.R., T.F, A.F.D., A.G.P. performed the experiments. T.A.R., T.F., A.F.D., A.G.P., C.P.G., J.E.A. wrote and edited the manuscript.

\section{REFERENCES}

1. Vögtle, F.-N. et al. Global analysis of the mitochondrial N-proteome identifies a processing peptidase critical for protein stability. Cell 139, 428-39 (2009).

2. Karamyshev, A. L. et al. Inefficient SRP interaction with a nascent chain triggers a mRNA quality control pathway. Cell 156, 146-57 (2014).

3. Rodrigues, T. A. et al. A PEX7-centered perspective on the peroxisomal targeting signal type 2-mediated protein import pathway. Mol. Cell. Biol. 34, 2917-28 (2014).

4. Paila, Y. D. et al. Multi-functional roles for the polypeptide transport associated domains of Toc75 in chloroplast protein import. Elife 5, (2016).

5. Miura, S., Miyazawa, S., Osumi, T., Hashimoto, T. \& Fujiki, Y. Post-translational import of 3-ketoacyl-CoA thiolase into rat liver peroxisomes in vitro. J. Biochem. 115, 1064-8 (1994).

6. Small, G. M., Imanaka, T., Shio, H. \& Lazarow, P. B. Efficient association of in vitro translation products with purified stable Candida tropicalis peroxisomes. Mol. Cell. Biol. 7, 1848-55 (1987).

7. Thieringer, R., Shio, H., Han, Y. S., Cohen, G. \& Lazarow, P. B. Peroxisomes in Saccharomyces cerevisiae: immunofluorescence analysis and import of catalase A into isolated peroxisomes. Mol. Cell. Biol. 11, 510-22 (1991).

8. Brickner, D. G., Harada, J. J. \& Olsen, L. J. Protein transport into higher plant peroxisomes. In vitro import assay provides evidence for receptor involvement. Plant Physiol. 113, 1213-21 (1997).

9. Brickner, D. G. \& Olsen, L. J. Nucleotide triphosphates are required for the transport 
of glycolate oxidase into peroxisomes. Plant Physiol. 116, 309-17 (1998).

10. Grou, C. P. et al. The peroxisomal protein import machinery - A case report of transient ubiquitination with a new flavor. Cell. Mol. Life Sci. 66, 254-262 (2009).

11. Kim, P. K. \& Hettema, E. H. Multiple Pathways for Protein Transport to Peroxisomes. J. Mol. Biol. 427, 1176-1190 (2015).

12. Baker, A. \& Paudyal, R. The life of the peroxisome: from birth to death. Curr. Opin. Plant Biol. 22, 39-47 (2014).

13. Rodrigues, T. A., Grou, C. P. \& Azevedo, J. E. Revisiting the intraperoxisomal pathway of mammalian PEX7. Sci. Rep. 5, 11806 (2015).

14. Freitas, M. O. et al. The peroxisomal protein import machinery displays a preference for monomeric substrates. Open Biol. 5, 140236 (2015).

15. Alexson, S. E. H., Fujiki, Y., Shio, H. \& Lazarow, P. B. Partial Disassembly of Peroxisomes. J. Cell Biol. 101, 294-305 (1985).

16. Brocard, C. \& Hartig, A. Peroxisome targeting signal 1: is it really a simple tripeptide? Biochim. Biophys. Acta 1763, 1565-73 (2006).

17. Oliveira, M. E., Gouveia, A. M., Pinto, R. A., Sá-Miranda, C. \& Azevedo, J. E. The energetics of Pex5p-mediated peroxisomal protein import. J. Biol. Chem. 278, 39483-8 (2003).

18. Gouveia, A. M. et al. Characterization of the peroxisomal cycling receptor, Pex $5 \mathrm{p}$, using a cell-free in vitro import system. J. Biol. Chem. 278, 226-32 (2003).

19. Gouveia, A. M., Guimarães, C. P., Oliveira, M. E., Sá-Miranda, C. \& Azevedo, J. E. Insertion of Pex5p into the peroxisomal membrane is cargo protein-dependent. $J$. Biol. Chem. 278, 4389-92 (2003).

20. Gouveia, A. M., Reguenga, C., Oliveira, M. E., Sa-Miranda, C. \& Azevedo, J. E. Characterization of peroxisomal Pex 5p from rat liver. Pex5p in the Pex5p-Pex 14p membrane complex is a transmembrane protein. J. Biol. Chem. 275, 32444-51 (2000).

21. Carvalho, A. F. et al. Ubiquitination of mammalian Pex5p, the peroxisomal import receptor. J. Biol. Chem. 282, 31267-72 (2007).

22. Miyata, N. \& Fujiki, Y. Shuttling Mechanism of Peroxisome Targeting Signal Type 1 Receptor Pex5 : ATP-Independent Import and ATP-Dependent Export. Mol. Cell. Biol. 25, 10822-10832 (2005).

23. Grou, C. P. et al. Properties of the ubiquitin-pex 5p thiol ester conjugate. J. Biol. Chem. 284, 10504-13 (2009).

24. Bhogal, M. S., Lanyon-Hogg, T., Johnston, K. A., Warriner, S. L. \& Baker, A. Covalent Label Transfer between Peroxisomal Importomer Components Reveals Export-driven Import Interactions. J. Biol. Chem. 291, 2460-8 (2016).

25. Platta, H. W., Grunau, S., Rosenkranz, K., Girzalsky, W. \& Erdmann, R. Functional role of the AAA peroxins in dislocation of the cycling PTS1 receptor back to the cytosol. Nat. Cell Biol. 7, 817-22 (2005).

26. Alencastre, I. S. et al. Mapping the cargo protein membrane translocation step into the PEX5 cycling pathway. J. Biol. Chem. 284, 27243-51 (2009).

27. Francisco, T. et al. A cargo-centered perspective on the PEX5-mediated peroxisomal protein import pathway. J. Biol. Chem. 288, 29151-29159 (2013).

28. Williams, C. P. et al. The Peroxisomal Targeting Signal 1 in sterol carrier protein 2 is autonomous and essential for receptor recognition. BMC Biochem. 12, 12 (2011).

29. Williams, C., van den Berg, M., Sprenger, R. R. \& Distel, B. A conserved cysteine is 
essential for Pex4p-dependent ubiquitination of the peroxisomal import receptor Pex5p. J. Biol. Chem. 282, 22534-43 (2007).

30. Grou, C. P. et al. Identification of ubiquitin-specific protease 9X (USP9X) as a deubiquitinase acting on the ubiquitin-peroxin 5 (PEX5) thioester conjugate. J. Biol. Chem. 287, 12815-27 (2012).

31. Debelyy, M. O. et al. Ubp15p, a ubiquitin hydrolase associated with the peroxisomal export machinery. J. Biol. Chem. 286, 28223-34 (2011).

32. Leighton, F., Poole, B., Lazarow, P. B. \& De Duve, C. The synthesis and turnover of rat liver peroxisomes. I. Fractionation of peroxisome proteins. J. Cell Biol. 41, 52135 (1969).

33. Grou, C. P. et al. Members of the E2D (UbcH5) family mediate the ubiquitination of the conserved cysteine of Pex5p, the peroxisomal import receptor. J. Biol. Chem. 283, 14190-7 (2008).

34. Okumoto, K. et al. Cysteine ubiquitination of PTS1 receptor Pex5p regulates Pex 5p recycling. Traffic 12, 1067-83 (2011).

35. Wendland, M. \& Subramani, S. Cytosol-dependent peroxisomal protein import in a permeabilized cell system. J. Cell Biol. 120, 675-85 (1993).

36. Koepke, J. I. et al. Restoration of peroxisomal catalase import in a model of human cellular aging. Traffic 8, 1590-600 (2007).

37. Terlecky, S. R., Legakis, J. E., Hueni, S. E. \& Subramani, S. Quantitative analysis of peroxisomal protein import in vitro. Exp. Cell Res. 263, 98-106 (2001).

38. Pinto, M. P. et al. The import competence of a peroxisomal membrane protein is determined by Pex 19p before the docking step. J. Biol. Chem. 281, 34492-34502 (2006).

39. Ghosh, D. \& Berg, J. M. A proteome-wide perspective on peroxisome targeting signal 1(PTS1)-Pex5p affinities. J. Am. Chem. Soc. 132, 3973-9 (2010).

40. Miyata, N., Okumoto, K., Mukai, S., Noguchi, M. \& Fujiki, Y. AWP1/ZFAND6 functions in Pex 5 export by interacting with cys-monoubiquitinated Pex 5 and Pex6 AAA ATPase. Traffic 13, 168-83 (2012).

41. Croes, K., Foulon, V., Casteels, M., Van Veldhoven, P. P. \& Mannaerts, G. P. Phytanoyl-CoA hydroxylase: recognition of 3-methyl-branched acyl-coAs and requirement for GTP or ATP and $\mathrm{Mg}(2+)$ in addition to its known hydroxylation cofactors. J. Lipid Res. 41, 629-36 (2000).

42. Miura, S. et al. Biosynthesis and intracellular transport of enzymes of peroxisomal beta-oxidation. J. Biol. Chem. 259, 6397-402 (1984).

43. Schram, A. W. et al. Biosynthesis and maturation of peroxisomal beta-oxidation enzymes in fibroblasts in relation to the Zellweger syndrome and infantile Refsum disease. Proc. Natl. Acad. Sci. U. S. A. 83, 6156-8 (1986).

44. Ossendorp, B. C. et al. Tissue-specific distribution of a peroxisomal 46-kDa protein related to the $58-\mathrm{kDa}$ protein (sterol carrier protein $\mathrm{x}$; sterol carrier protein 2/3oxoacyl-CoA thiolase). Arch. Biochem. Biophys. 334, 251-60 (1996).

45. Braverman, N., Dodt, G., Gould, S. J. \& Valle, D. An isoform of pex5p, the human PTS1 receptor, is required for the import of PTS2 proteins into peroxisomes. Hum. Mol. Genet. 7, 1195-205 (1998).

46. Lazarow, P. B. The import receptor Pex7p and the PTS2 targeting sequence. Biochim. Biophys. Acta 1763, 1599-604 (2006).

47. Kunze, M. et al. Structural requirements for interaction of peroxisomal targeting 
signal 2 and its receptor PEX7. J. Biol. Chem. 286, 45048-62 (2011).

48. Otera, H. et al. Peroxisome targeting signal type 1 (PTS1) receptor is involved in import of both PTS1 and PTS2: studies with PEX5-defective CHO cell mutants. Mol. Cell. Biol. 18, 388-99 (1998).

49. Fujiki, Y., Matsuzono, Y., Matsuzaki, T. \& Fransen, M. Import of peroxisomal membrane proteins: the interplay of Pex3p- and Pex19p-mediated interactions. Biochim. Biophys. Acta 1763, 1639-46 (2006).

50. Freitas, M. O. et al. PEX5 protein binds monomeric catalase blocking its tetramerization and releases it upon binding the N-terminal domain of PEX14. $J$. Biol. Chem. 286, 40509-40519 (2011).

51. Dodt, G. et al. Mutations in the PTS1 receptor gene, PXR1, define complementation group 2 of the peroxisome biogenesis disorders. Nat. Genet. 9, 115-25 (1995).

52. Gatto, G. \& Geisbrecht, B. Peroxisomal targeting signal-1 recognition by the TPR domains of human PEX5. Nat. Struct. Biol. 7, 1091-1095 (2000).

53. Szilard, R. K. \& Rachubinski, R. A. Tetratricopeptide repeat domain of Yarrowia lipolytica Pex $5 p$ is essential for recognition of the type 1 peroxisomal targeting signal but does not confer full biological activity on Pex5p. Biochem. J. 346 Pt 1, 177-84 (2000).

54. Carvalho, A. F. et al. Functional characterization of two missense mutations in Pex5p - C11S and N526K. Biochim. Biophys. Acta 1773, 1141-8 (2007).

55. Nordgren, M. et al. Export-deficient monoubiquitinated PEX5 triggers peroxisome removal in SV40 large T antigen-transformed mouse embryonic fibroblasts. Autophagy 11, 1326-40 (2015).

56. Carvalho, A. F. et al. The N-terminal half of the peroxisomal cycling receptor Pex 5p is a natively unfolded domain. J. Mol. Biol. 356, 864-75 (2006).

57. Schliebs, W. et al. Recombinant Human Peroxisomal Targeting Signal Receptor PEX5: Sructural basis for interaction of PEX5 with PEX14. J. Biol. Chem. 274, 5666-5673 (1999).

58. Otera, H. et al. Peroxisomal targeting signal receptor Pex $5 p$ interacts with cargoes and import machinery components in a spatiotemporally differentiated manner: conserved Pex5p WXXXF/Y motifs are critical for matrix protein import. Mol. Cell. Biol. 22, 1639-1655 (2002).

59. Costa-Rodrigues, J. et al. The N terminus of the peroxisomal cycling receptor, Pex $5 \mathrm{p}$, is required for redirecting the peroxisome-associated peroxin back to the cytosol. J. Biol. Chem. 279, 46573-9 (2004).

60. Hwang, S. T. \& Schatz, G. Translocation of proteins across the mitochondrial inner membrane, but not into the outer membrane, requires nucleoside triphosphates in the matrix. Proc. Natl. Acad. Sci. U. S. A. 86, 8432-6 (1989).

61. Haas, A. L., Warms, J. \& Rose, I. A. Ubiquitin adenylate: structure and role in ubiquitin activation. Biochemistry 22, 4388-94 (1983).

62. Pickart, C. M. \& Rose, I. A. Ubiquitin carboxyl-terminal hydrolase acts on ubiquitin carboxyl-terminal amides. J. Biol. Chem. 260, 7903-10 (1985).

63. Costa-Rodrigues, J. et al. Pex 5p, the peroxisomal cycling receptor, is a monomeric non-globular protein. J. Biol. Chem. 280, 24404-24411 (2005).

64. Ferro, A. et al. NEDD8: a new ataxin-3 interactor. Biochim. Biophys. Acta 1773, 1619-27 (2007).

65. Fransen, M., Wylin, T., Brees, C., Mannaerts, G. P. \& Veldhoven, P. P. Van. Human 
Pex19p Binds Peroxisomal Integral Membrane Proteins at Regions Distinct from Their Sorting Sequences. Mol. Cell. Biol. 21, 4413-4424 (2001). 


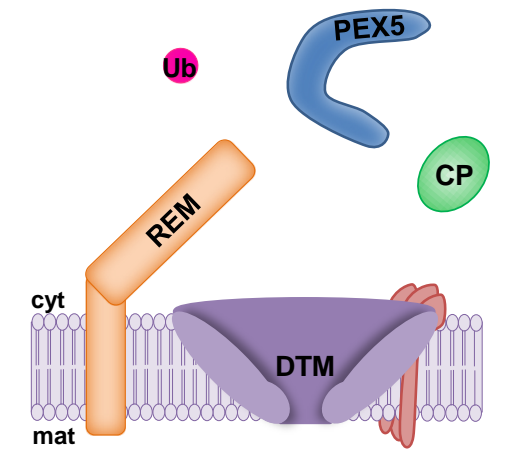

Stage 0

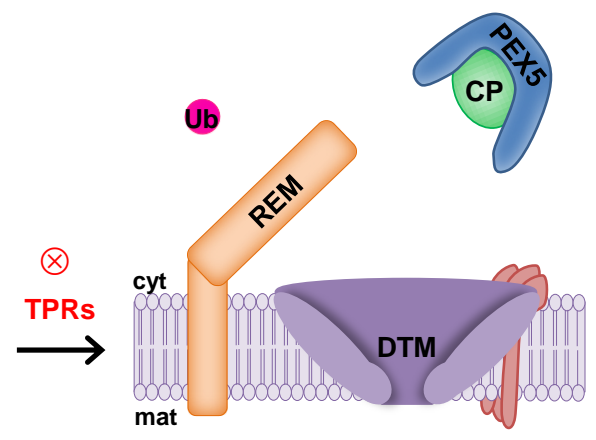

Stage 1a
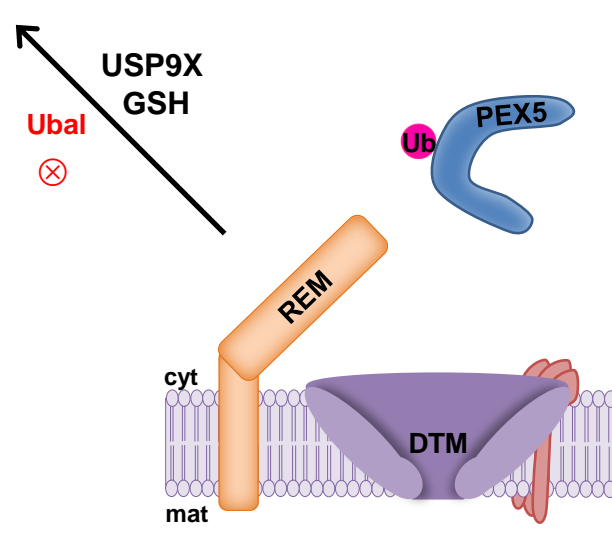

Stage 4

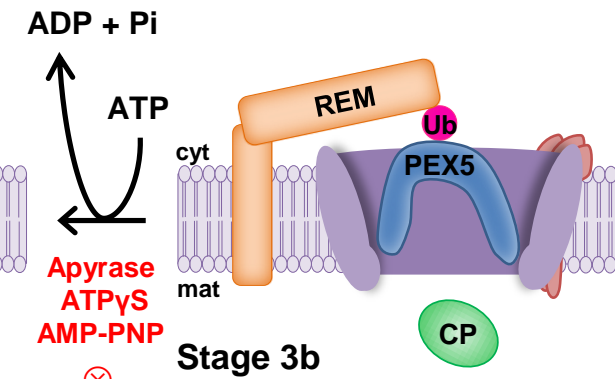

$\otimes$

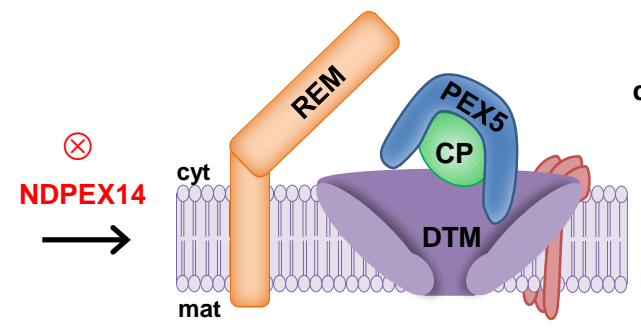

Stage 1b

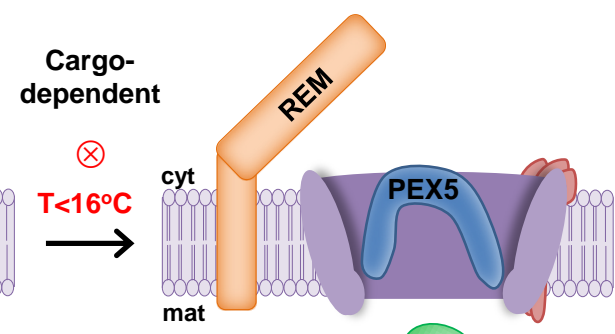

Stage 2

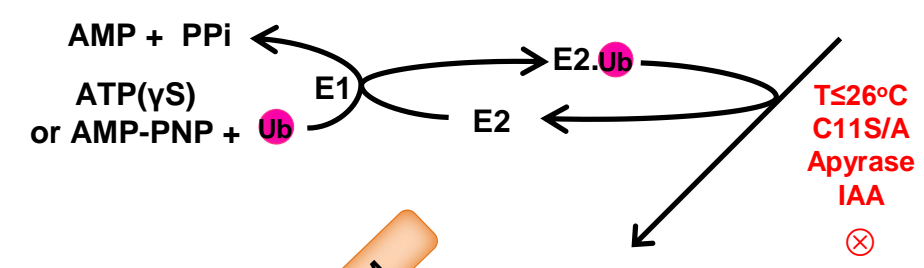

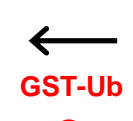

$\otimes$

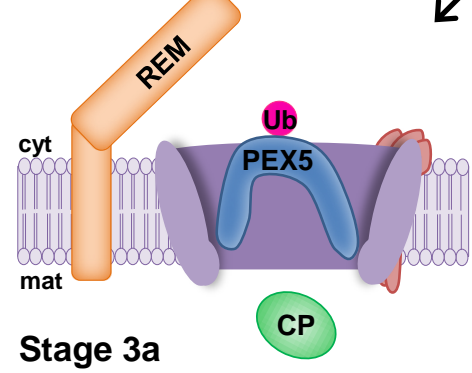

$\otimes$ 
a

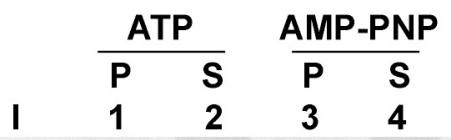

97-

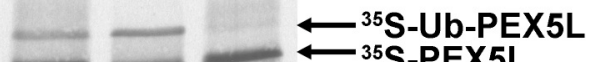

66-

97-

66-

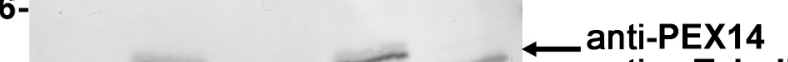

45-

97-

66-

45-

C

\begin{tabular}{rrrrrrr} 
& & & \multicolumn{3}{c}{ Pre-incubation } \\
PEX5L & - & + & + & + & + \\
NDPEX14 & - & - & - & + & - \\
PEX19 & - & - & - & - & + \\
$\mathrm{I}_{1} \mathrm{I}_{2}$ & 1 & 2 & 3 & 4 & 5
\end{tabular}

66-

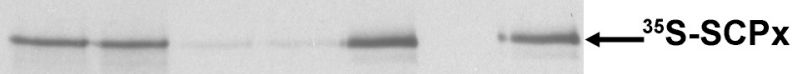

45-

anti-Catalase

66-

45-

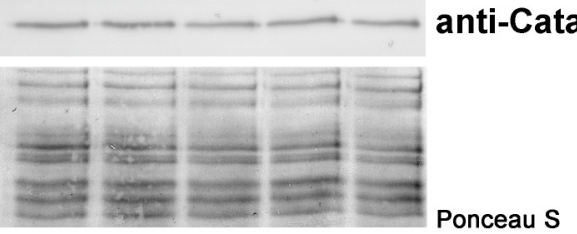

b

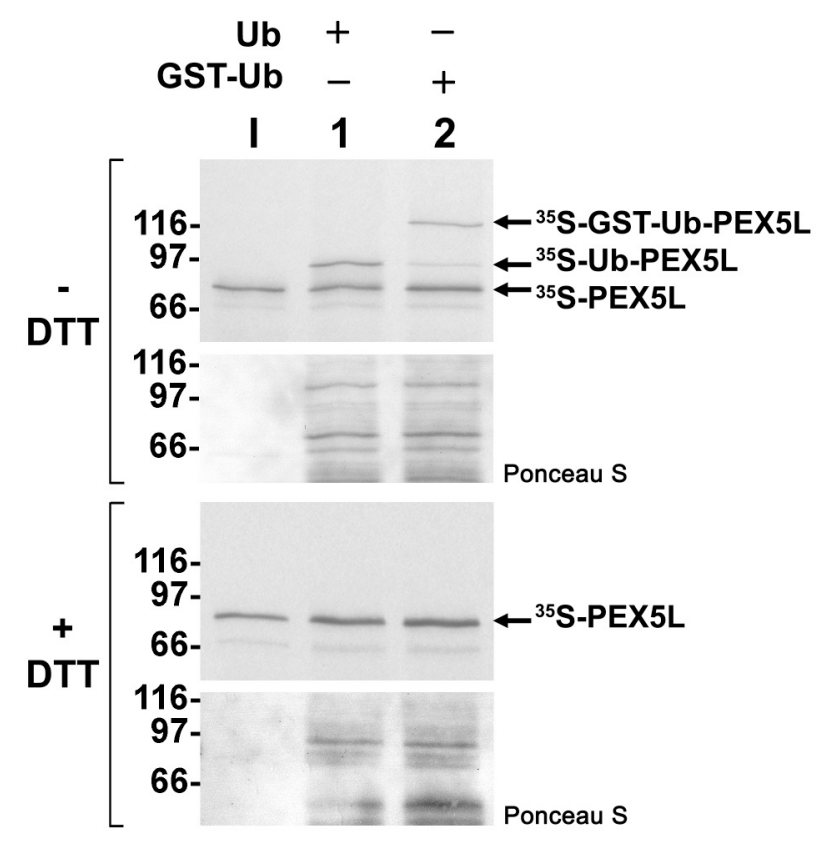

d

$\begin{array}{rcccccc}\triangle \text { C1PEX5S } & - & + & - & - & - & - \\ \triangle \text { C1PEX5L } & - & - & + & + & + & + \\ \text { PrePHYH } & - & - & - & + & - & + \\ \text { matPHYH } & - & - & - & - & + & - \\ \text { NDPEX14 } & - & - & - & - & - & + \\ \text { I } & 1 & 2 & 3 & 4 & 5 & 6\end{array}$

45-

31.

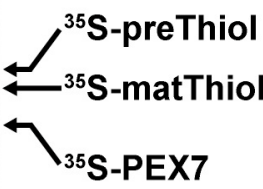

anti-Catalase

45-

31-

Ponceau S 